\title{
Petrology of the eclogites from western Tasmania: Insights into the Cambro-Ordovician evolution of the paleo-Pacific margin of Gondwana
}

\author{
R. Palmeri a, ${ }^{\text {a, }}$ R. Chmielowski ${ }^{\text {b }}$, S. Sandroni ${ }^{\text {c }}$, F. Talarico ${ }^{\text {c }}$, C.A. Ricci ${ }^{\text {a,c }}$ \\ ${ }^{a}$ Museo Nazionale dell'Antartide, via Laterina 8, 53100 Siena, Italy \\ b Centre for Ore Deposit Research, University of Tasmania, Private Bag 79, Hobart, Australia \\ c Dipartimento di Scienze della Terra, via Laterina 8, 53100 Siena, Italy
}

\section{A R T I C L E I N F O}

\section{Article history:}

Received 28 January 2008

Accepted 27 June 2008

Available online 8 July 2008

\section{Keywords:}

Eclogite

High-pressure metamorphism

Tasmania

Antarctica

Gondwana

Ross/Tyennan orogen

\begin{abstract}
A B S T R A C T
Eclogite facies rocks along the Paleozoic active margin of Gondwana are rare. They are limited to isolated segments of Northern Victoria Land (Antarctica), western Tasmania, and southeastern Australia. New petrological data for mafic rocks and their host garnet-kyanite schists from the Franklin Metamorphic Complex (western Tasmania) permit reconstruction of six main stages of mineral growth for the eclogite. Stages I and II occurred at greenschist/ amphibolite-facies conditions (ca. 500-600 ${ }^{\circ} \mathrm{C}$; $0.55-0.7 \mathrm{GPa}$ for stage II) before attaining high-pressure conditions (at $\approx 600-650^{\circ} \mathrm{C} ;>1.5 \mathrm{GPa}$ for stage III). The following stages, IV and V, record the decompression from high-pressure conditions to amphibolite-facies (ca. $500-600^{\circ} \mathrm{C} ; 0.4-1.0 \mathrm{GPa}$ ). Finally, stage VI represents the late greenschist-facies retrogression. However, the pelitic schist surrounding the eclogite records only the mediumpressure amphibolite-facies stage. The $P-T$ evolution over time outlines a clockwise path that is quite steep in both the prograde and retrograde segments. The latter shows a nearly isothermal decompression between the eclogite and the high-pressure amphibolite-facies stage IV, which was achieved at deep crustal levels ( $\approx 30 \mathrm{~km})$, and a final decrease in both pressure and temperature from deep/intermediate to shallow crustal levels, with a typical cooling-unloading path. The lack of a complete re-equilibration during the different stages and the high $\mathrm{dP} / \mathrm{d} T$ for both the prograde and retrograde paths are indicative of a rapid burial and initially rapid exhumation. The similarity of the mafic whole-rock chemical composition, including N, T to E-MORB and of the peak metamorphic age $(\approx 500 \mathrm{Ma}$ ) between the Tasmanian eclogites and the UHP rocks from Northern Victoria Land, supports the idea that they formed in the context of the same contractional event. However, the different $P-T$ conditions and $\mathrm{d} P / \mathrm{d} T$ point to different tectono-metamorphic settings for the two sectors of the paleo-Pacific margin of Gondwana during the Ross/Tyennan orogeny.
\end{abstract}

(c) 2008 Elsevier B.V. All rights reserved.

\section{Introduction}

From the late Precambrian to the early Paleozoic, the East Gondwana margin changed from a passive to an active margin. Subductionrelated orogenic activity produced the Cambrian/Ordovician deformation, metamorphism, and magmatism known as the Ross, Delamerian, and Tyennan orogeny in Antarctica, southern Australia, and Tasmania, respectively (Kleinschmidt and Tessensohn, 1987; Flöttmann et al., 1993; Borg and DePaolo, 1994; Ricci et al., 1997; Foster et al., 2005; Squire and Wilson, 2005). Eclogite facies rocks in metamorphic terrains are important indicators of paleo-plate sutures and provide valuable constraints on tectonic and thermal models for the evolution of plate subduction/collision zones (Carswell, 1990). Eclogite facies rocks along the paleo-Pacific margin of Gondwana are rare. They have been described in Northern Victoria Land (Antarctica), western Tas-

\footnotetext{
* Corresponding author. Tel.: +39 577 233893; fax: +39 577233890.

E-mail addresses: palmerir@unisi.it (R. Palmeri), reiac0@utas.edu.au (R.Chmielowski), sandroni@unisi.it (S. Sandroni), talarico@unisi.it (F. Talarico), riccia@unisi.it (C.A. Ricci).
}

mania and southeastern Australia, and they formed at an early Paleozoic convergent plate boundary close to the eastern margin of Gondwana (Turner et al., 1998; Palmeri et al., 2007 and reference therein; Och et al., 2003).

Tyennan Orogeny rocks of Tasmania represent an important link between the Cambro-Ordovician rocks in Antarctica and southern Australia. According to Meffre et al. (2000), there is no agreement among various authors as to whether Tasmania should be displaced from its present position - westwards to line up the western edge of the Lachlan Fold Belt in both Tasmania and the mainland Australia, or eastwards, so that Tasmania becomes an allochthonous terrane.

The aim of this paper is to define the metamorphic character of the eclogites and of their hosting pelitic schists cropping out in the Franklin Metamorphic Complex of western Tasmania through fabric relationships, mineral compositions, assemblages, and thermobarometric estimates. These characteristics, and the comparison with similar coeval rocks from Northern Victoria Land (Di Vincenzo et al., 1997; Palmeri et al., 2003) form the basis of a discussion about the tectono-metamorphic evolution of high-pressure rocks along the early Paleozoic paleo-Pacific margin of Gondwana. 


\section{Geological setting of Tasmania}

Tasmania is a key region located between the Cambro-Ordovician rocks of the Ross Orogen in Northern Victoria Land and the Lachlan Fold Belt in southern mainland Australia (Fig. 1A, B, C). In addition, these three areas contain eclogite facies rocks, which are rare along the Paleozoic active margin of Gondwana (Goodge, 2007; Foster et al., 2005).

In Tasmania, the Neoproterozoic-Cambrian metamorphic rocks involved in the Tyennan Orogeny are confined to the western and northern areas (Fig. 1C). In western Tasmania, the Neoproterozoic-early
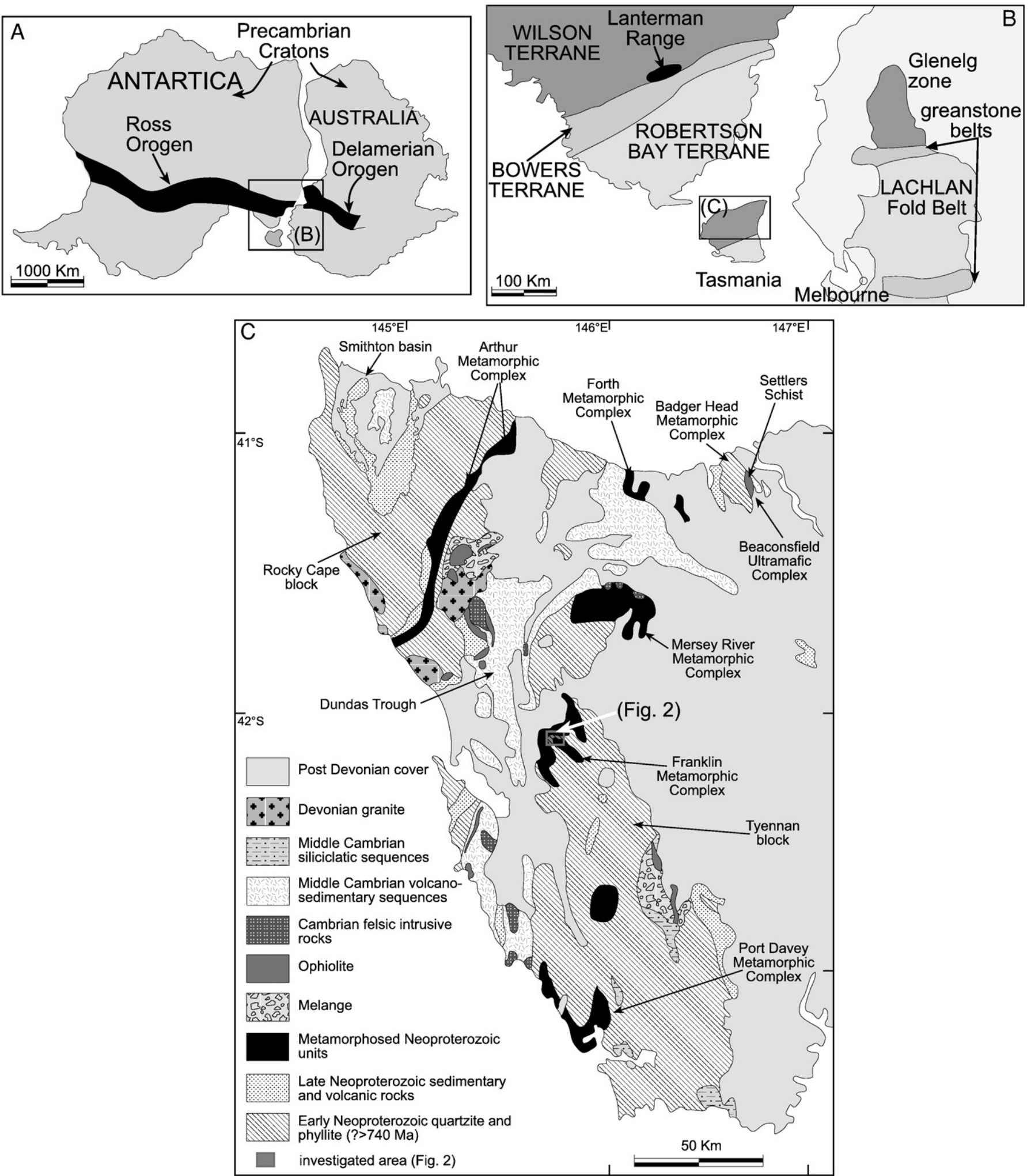

Fig. 1. (A) Configuration of Antarctica, Australia, and Tasmania during Cambro-Ordovician times (modified after Foden et al., 2006); (B) tectonic sketch map showing the different structural zones of Northern Victoria Land (Antarctica), Tasmania, and southeast Australia (after Flöttmann et al., 1993, Foden et al., 2006); (C) geological map of western Tasmania (modified after Meffre et al., 2000). 
Cambrian passive margin consists of continental-derived turbidite intercalated with basalt and intruded by dolerite dykes and sills, and it overlies early Neoproterozoic shallow-water sedimentary rocks (Fig. 2C; Meffre et al., 2000). The passive margin of Tasmania was involved in a collision with an island arc system at the beginning of the convergent stage of the Delamerian-Tyennan-Ross Orogeny (520 to $505 \mathrm{Ma}$ )
(Crawford \& Berry, 1992; Foster et al., 2005; Foden et al., 2006). The collision generated a Tethyan-style ophiolite complex containing abundant mafic-ultramafic rocks including boninities. High-pressure metamorphic rocks in this complex formed from fragments of the continental margin (Berry and Crawford, 1988; Crawford and Berry, 1992; Turner et al., 1998; Meffre et al., 2000; Foster et al., 2005). This
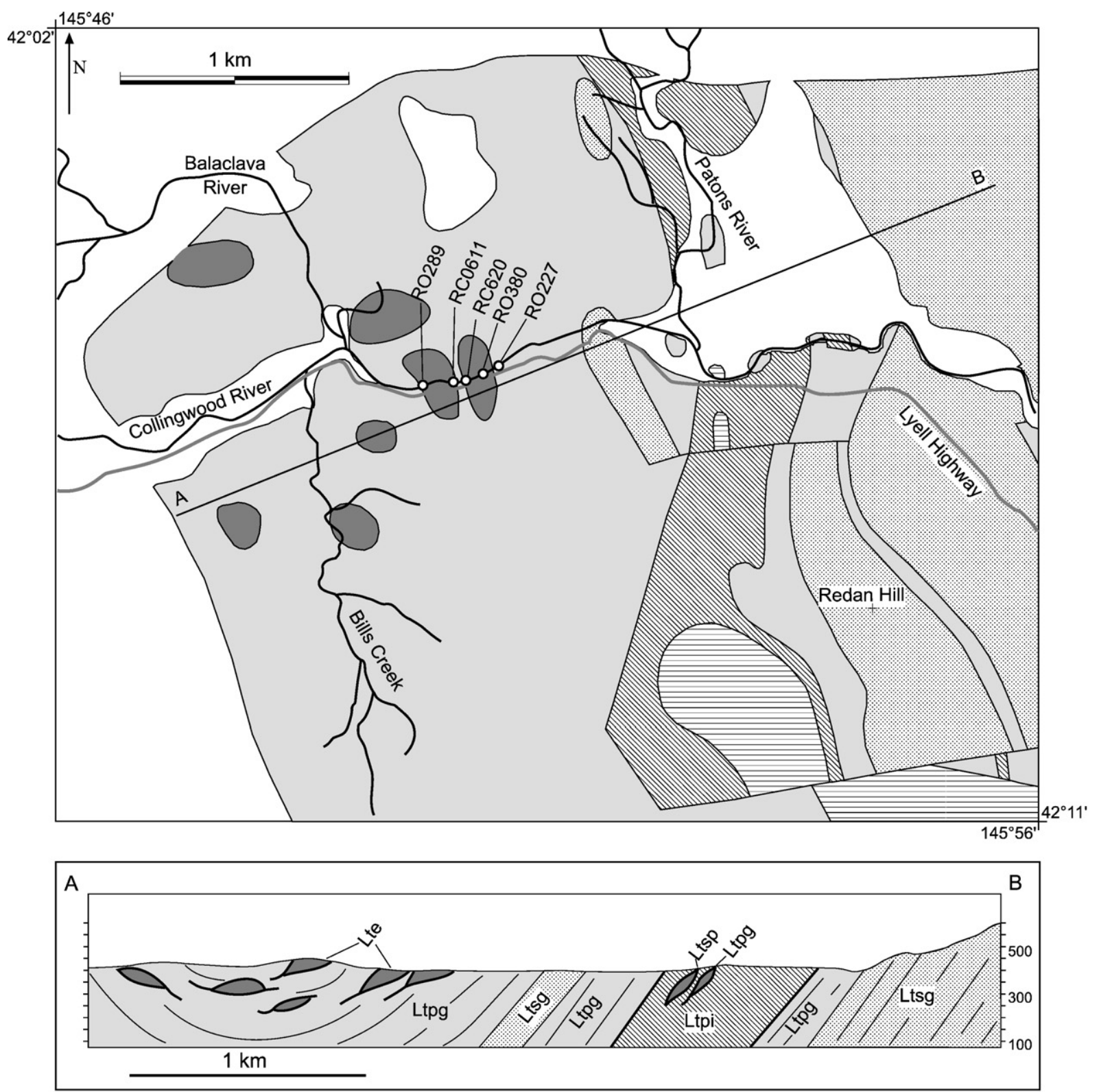

\begin{tabular}{|c|c|c|c|}
\hline Ltpg & $\begin{array}{l}\text { Fine- to coarse-grained, often thinly banded, pelitic, } \\
\text { garnetiferous quartz-mica and mica-quartz schist, } \\
\text { commonly containing phengite, biotite, almandine, } \\
\text { albite and chlorite. Relatively high-metamorphic } \\
\text { grade. }\end{array}$ & 莑Ltsp & $\begin{array}{l}\text { Interbanded fine-grained phengitic quartzite, green } \\
\text { phengite-quartz phyllite and grey to green } \\
\text { carbonaceous pelitic quartz-phengite phyllite. Non- } \\
\text { garnetiferous and relatively low-metamorphic grade. }\end{array}$ \\
\hline Lte & Local occurrences of amphibolite and eclogite. & Ltsg & $\begin{array}{l}\text { Massive and schistose quartzite, fine to coarse } \\
\text { grained, commonly containing phengite, almandine } \\
\text { and chlorite. }\end{array}$ \\
\hline Ltpi & $\begin{array}{l}\text { Dominantly dark grey carbonaceous quartz-mica } \\
\text { phyllite, sometimes porphyroblastic and occasionally } \\
\text { containing albite, biotite, phengite, chlorite and minor } \\
\text { garnet; fine-grained quartzite frequently present. } \\
\text { Intermediate-metamorphic grade. }\end{array}$ & 0 & Study samples. \\
\hline
\end{tabular}

Fig. 2. Geological sketch map of the Collingwood River-Lyell Highway area of the Franklin Metamorphic Complex showing sample locations. A-B: Location of the geological section. Map adapted from (Brown et al., 2005). 

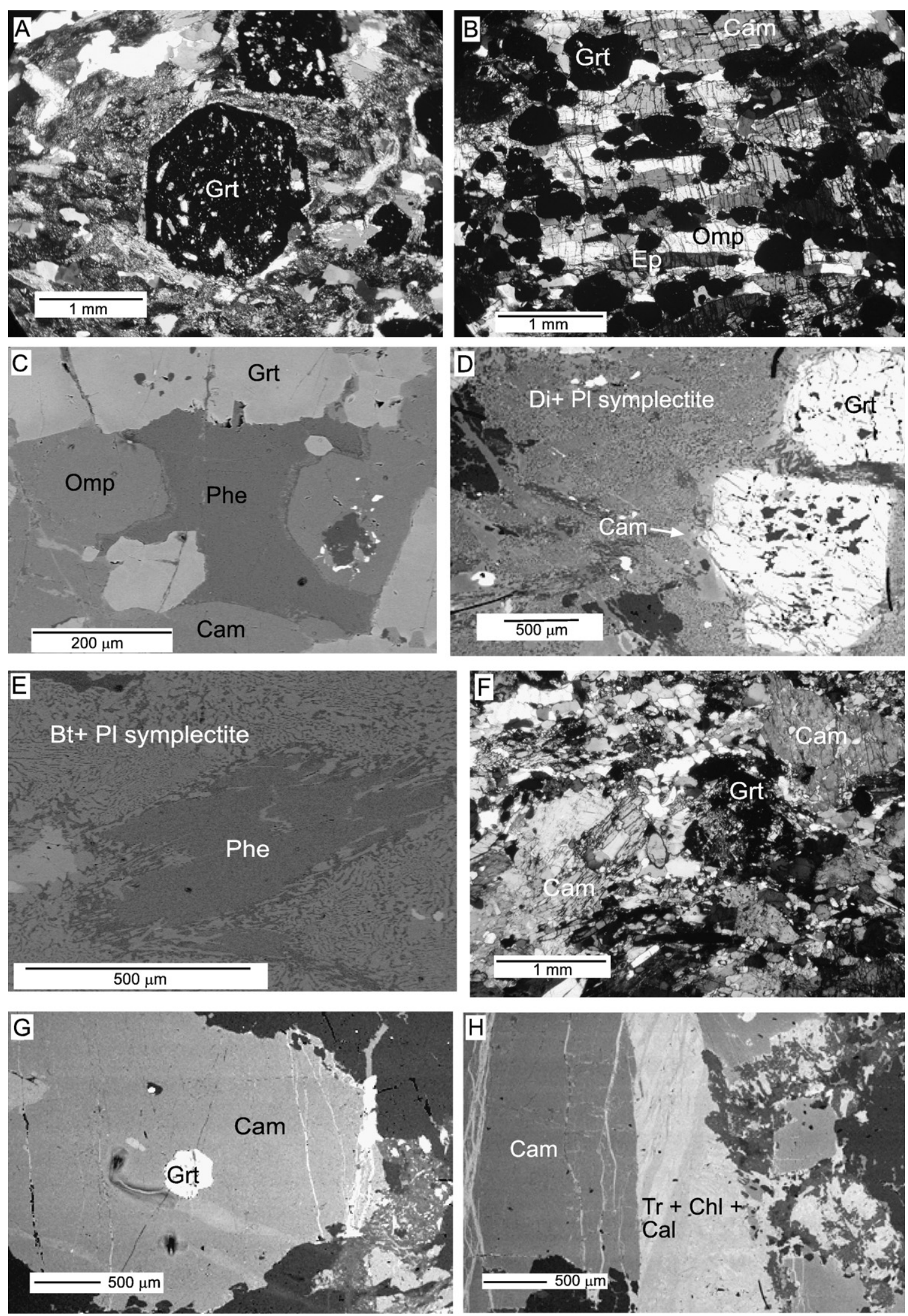

Fig. 3. Photomicrographs of microstructures in eclogite from the Collingwood River (Tasmania). Mineral symbols after Kretz (1983) and Phe for phengite. (A) Euhedral porphyroblastic garnet with abundant inclusions in a partly retrogressed matrix. Crossed nicols, sample RCo611. (B) Fine-grained layer showing textural equilibrium among Grt, Omp, Cam, and Ep. Crossed nicols, sample RO380. (C) Backscattered scanning electron microscope (BSE-SEM) image showing the good textural equilibrium among the mineral phases defining the eclogite facies stage III. Sample RO380. (D) Porphyroblastic garnet and the Di + Pl symplectite after omphacite. Crossed nicols, sample RCO611. (E) BSE-SEM image of a phengite relic surrounded by its destabilization products ( $\mathrm{Bt}+\mathrm{Pl}$ symplectite). Sample RO380. (F) Anhedral garnet relics, together with abundant porphyroblastic amphiboles. Crossed nicols, sample RO289. (G) BSE image of a porphyroblastic amphibole with a garnet relic as inclusion. Sample RO380. (H) BSE image of a late vein cross-cutting a porphyroblastic amphibole. The vein consists of an association of chlorite, tremolite, and calcite. Sample RO380. 
Table 1

Representative garnet analyses for eclogite

\begin{tabular}{|c|c|c|c|c|c|c|c|c|c|c|c|c|c|c|c|c|c|c|c|c|}
\hline \multirow{3}{*}{$\begin{array}{l}\text { Sample } \\
\text { No. }\end{array}$} & \multicolumn{8}{|l|}{ RC611 } & \multicolumn{12}{|l|}{ RO380 } \\
\hline & \multicolumn{8}{|l|}{ Grt1 } & \multicolumn{7}{|l|}{ Grt2 } & \multicolumn{5}{|l|}{ Grt3 } \\
\hline & P3-r & P11-r & P24-m & P41-m & P70-c & P83-c & P102-m & P144-r & P13-rim & P24-m & P37-c & P40-c & P49-m & P74-m & P85-r & P4-r & P15-m & P37-c & P55-m & P78-r \\
\hline$\overline{\mathrm{SiO}_{2}}$ & 39.77 & 39.86 & 39.09 & 39.11 & 38.03 & 38.25 & 38.89 & 39.49 & 39.39 & 38.31 & 39.00 & 39.00 & 39.07 & 38.46 & 39.63 & 39.82 & 39.28 & 39.55 & 39.65 & 39.93 \\
\hline $\mathrm{Al}_{2} \mathrm{O}_{3}$ & 22.34 & 22.37 & 21.87 & 21.85 & 21.60 & 21.45 & 22.01 & 22.16 & 22.23 & 21.81 & 22.01 & 22.27 & 22.06 & 21.78 & 22.54 & 22.34 & 22.09 & 21.88 & 22.08 & 22.33 \\
\hline $\mathrm{TiO}_{2}$ & 0.09 & 0.03 & 0.09 & 0.15 & 0.06 & 0.08 & 0.14 & 0.09 & 0.07 & 0.03 & 0.14 & 0.09 & 0.26 & 0.08 & 0.00 & 0.09 & 0.06 & 0.22 & 0.13 & 0.02 \\
\hline $\mathrm{Cr}_{2} \mathrm{O}_{3}$ & 0.02 & 0.04 & 0.07 & 0.06 & 0.01 & 0.07 & 0.05 & 0.12 & 0.09 & 0.04 & 0.02 & 0.03 & 0.00 & 0.02 & 0.07 & 0.09 & 0.07 & 0.02 & 0.03 & 0.06 \\
\hline $\mathrm{FeO}$ & 20.58 & 21.03 & 21.75 & 20.51 & 25.39 & 25.58 & 21.86 & 22.18 & 18.50 & 23.43 & 20.80 & 19.27 & 22.15 & 23.81 & 18.62 & 20.30 & 20.61 & 20.97 & 20.37 & 20.54 \\
\hline MnO & 0.34 & 0.34 & 0.69 & 0.64 & 1.97 & 1.73 & 0.89 & 0.50 & 0.28 & 0.41 & 0.52 & 0.55 & 0.54 & 0.37 & 0.32 & 0.35 & 0.37 & 0.72 & 0.57 & 0.40 \\
\hline MgO & 10.12 & 9.19 & 6.40 & 6.19 & 1.81 & 2.04 & 5.01 & 7.12 & 10.78 & 6.48 & 8.70 & 8.99 & 7.47 & 6.00 & 10.37 & 9.68 & 8.19 & 8.02 & 8.51 & 9.21 \\
\hline $\mathrm{CaO}$ & 7.93 & 8.55 & 11.01 & 12.43 & 12.37 & 12.30 & 12.44 & 10.02 & 8.39 & 9.54 & 9.00 & 9.97 & 9.09 & 9.83 & 8.74 & 8.52 & 10.02 & 9.74 & 9.84 & 8.57 \\
\hline Total & 101.19 & 101.41 & 100.97 & 100.94 & 101.24 & 101.50 & 101.30 & 101.69 & 99.74 & 100.04 & Err:522 & 100.18 & 100.63 & 100.36 & 100.29 & 101.19 & 100.68 & 100.19 & 101.18 & 101.06 \\
\hline \multicolumn{21}{|c|}{ Structural formulae on the basis of 12 oxygens } \\
\hline $\mathrm{Si}$ & 2.971 & 2.982 & 2.978 & 2.974 & 2.975 & 2.981 & 2.971 & 2.980 & 2.964 & 2.957 & 2.962 & 2.951 & 2.975 & 2.966 & 2.970 & 2.976 & 2.972 & 2.983 & 2.979 & 2.993 \\
\hline $\mathrm{Al}$ & 1.967 & 1.972 & 1.964 & 1.958 & 1.991 & 1.970 & 1.982 & 1.971 & 1.972 & 1.984 & 1.970 & 1.986 & 1.979 & 1.980 & 1.991 & 1.968 & 1.969 & 1.945 & 1.956 & 1.973 \\
\hline $\mathrm{Ti}$ & 0.005 & 0.001 & 0.005 & 0.009 & 0.004 & 0.005 & 0.008 & 0.005 & 0.004 & 0.002 & 0.008 & 0.005 & 0.015 & 0.005 & 0.000 & 0.005 & 0.003 & 0.012 & 0.008 & 0.001 \\
\hline $\mathrm{Cr}$ & 0.001 & 0.002 & 0.004 & 0.003 & 0.001 & 0.004 & 0.003 & 0.007 & 0.006 & 0.002 & 0.001 & 0.002 & 0.000 & 0.001 & 0.004 & 0.005 & 0.004 & 0.001 & 0.002 & 0.003 \\
\hline $\mathrm{Fe}^{3+}$ & 0.057 & 0.041 & 0.049 & 0.055 & 0.030 & 0.039 & 0.035 & 0.037 & 0.054 & 0.055 & 0.059 & 0.056 & 0.031 & 0.049 & 0.035 & 0.045 & 0.052 & 0.058 & 0.056 & 0.029 \\
\hline $\mathrm{Fe}^{2+}$ & 1.229 & 1.275 & 1.337 & 1.249 & 1.631 & 1.628 & 1.362 & 1.363 & 1.110 & 1.457 & 1.262 & 1.163 & 1.378 & 1.486 & 1.133 & 1.224 & $\begin{array}{l}1.252 \\
\text { S }\end{array}$ & 1.265 & $\begin{array}{l}1.224 \\
\text { S }\end{array}$ & 1.258 \\
\hline $\mathrm{Mn}$ & 0.022 & 0.021 & 0.045 & $\begin{array}{l}0.041 \\
0.041\end{array}$ & 0.130 & 0.114 & $\begin{array}{l}0.058 \\
0.058\end{array}$ & 0.032 & 0.018 & 0.027 & 0.034 & 0.035 & 0.035 & $\begin{array}{l}1.400 \\
0.024\end{array}$ & 0.021 & $\begin{array}{l}1.224 \\
0.022\end{array}$ & 0.024 & 0.046 & 0.036 & 0.025 \\
\hline $\mathrm{Mg}$ & 1.127 & 1.025 & 0.727 & 0.702 & 0.211 & 0.237 & 0.571 & 0.801 & 1.210 & 0.745 & 0.985 & 1.014 & 0.847 & 0.690 & 1.158 & $\begin{array}{l}1.079 \\
\end{array}$ & 0.923 & 0.901 & 0.953 & 1.030 \\
\hline $\mathrm{Ca}$ & 0.634 & 0.686 & 0.898 & 1.012 & 1.037 & 1.027 & 1.018 & 0.810 & 0.677 & 0.789 & 0.732 & 0.808 & 0.742 & 0.812 & 0.702 & 0.682 & 0.812 & 0.787 & 0.792 & 0.688 \\
\hline Total & 8.012 & 8.007 & 8.006 & 8.005 & 8.009 & 8.006 & 8.008 & 8.007 & 8.015 & 8.018 & 8.018 & 8.023 & 8.003 & 8.012 & 8.014 & 8.007 & 8.011 & 8.000 & 8.005 & 8.001 \\
\hline
\end{tabular}


stage was followed by post-collisional continental extension and magmatism at 505-495 Ma (Meffre et al., 2000; Black et al., 1997; Foster et al., 2005).

Metamorphic rocks formed and exhumed during the Tyennan Orogeny are related to the early stages (515-505 Ma) of orogeny and are linked to the ophiolite obduction, while metamorphic rocks dredged offshore to the South of Tasmania (SW Tasman Rise), show a younger metamorphism (500-495 Ma) that correlates with the late stage of the Ross Orogeny (Berry et al., 2007). The metamorphic complexes of Tasmania include (Fig. 1C) the Port Davey, Franklin, Mersey River, Arthur, Forth, and Badger Head Complexes (Meffre et al., 2000; Reed et al., 2002; Foster et al., 2005). They are located (Fig. 2C) east of the Neoproterozoic Rocky Cape Block and largely along the western margin of the Tyennan Block, but they include inliers northeast of the Tyennan Block (e.g., the Badger Head complex). The Franklin Metamorphic Complex is a fault-bounded slice that contains rocks with the highest metamorphic grades in Tasmania (Meffre et al. 2000). It consists of pelitic schists, minor phyllite, and quartzite, as well as lenses of amphibolite that locally preserve eclogite facies assemblages and white schists (Meffre et al., 2000 and references therein).

Compositionally, the amphibolites and the eclogites are similar to the unmetamorphosed dykes and basalts that are common in the Neoproterozoic of Tasmania and range from N- to E-MORB in character (Kamperman, 1984; Meffre et al., 2000). The most common amphibolites and eclogites are less evolved than the average Neoproterozoic basalts and probably originated as basaltic dykes that intruded into the continental margin sediments during a Neoproterozoic extensional event (Meffre et al., 2000). SHRIMP dating of zircons from the eclogite provides a Cambrian age for metamorphism ( $511 \pm 8 \mathrm{Ma}$, Black et al., 1997). It is worth noting that amphibolites and eclogites from Northern Victoria Land (Antarctica) range in composition from E-MORB through T-MORB to an orogenic calc-alkaline character, and they have a similar metamorphic age $(\approx 500 \mathrm{Ma})$, but the age of the mafic protolith is still poorly constrained (Di Vincenzo et al., 1997; Rocchi et al., 2003). In the Franklin Metamorphic Complex, the whole-rock chemistry of the host schists supports the idea that they originated from a sedimentary protolith (Meffre et al., 2000), and their metamorphic ages $(508 \pm 9 \mathrm{Ma})$, measured using the U-Th-Pb method on monazite, are the same as that of the eclogites (Berry et al., 2007).

High-pressure rocks in western Tasmania are also present in other metamorphic complexes such as the Arthur Metamorphic Complex and the Badger Head Complex (Turner and Bottrill, 2001; Reed et al., 2002), where blue-schist facies rocks, but no eclogite, have been found.

\section{Petrography and mineral chemistry of Tasmanian eclogites}

The eclogites included in this study are exposed in the Collingwood River area of western Tasmania as lenses or boudins (from meter to hectometer in size) within meta-sedimentary sequences mainly consisting of pelitic schist, interlayered quartzite, and lenses of phyllite (Fig. 2). The eclogite samples come from a (relatively) fresh outcrop in the bed of the Collingwood River (Fig. 2), but eclogite is also exposed in a road cut along the Lyell Highway, $20 \mathrm{~m}$ uphill from the riverbed, where it is more weathered. This road cut is the location from which eclogite was first reported in Tasmania (Spry, 1963). The eclogite boudins show a massive-to-layered texture, while the enclosing schists show a dominant and pervasive foliation, which typically dips steeply to the west and wraps around the lenses of eclogite. The foliation of host rocks is a schistosity that developed under amphibolite-facies metamorphic conditions, and it is defined by aligned growth of muscovite \pm biotite \pm garnet \pm talc. At the contact with the mafic boudins, the foliation is parallel to the margins, and a concordant, narrow foliation can also be seen in the eclogite. These narrow foliated margins show the development of amphibole and correspond to the most retrogressed portions of the boudin. The samples of hosting schist selected for this study, which came from the same outcrop as the eclogite and are structurally in contact with the eclogite boudins (Fig. 2), contain quartz-white mica-plagioclasegarnet-biotite with possible kyanite relics.

Table 2

Representative pyroxene analyses for eclogite.

\begin{tabular}{|c|c|c|c|c|c|c|c|c|c|c|c|c|c|}
\hline \multirow{3}{*}{$\begin{array}{l}\text { Sample } \\
\text { No. }\end{array}$} & \multicolumn{10}{|l|}{ RO380 } & \multirow{2}{*}{\multicolumn{3}{|c|}{$\frac{\text { RC611 }}{\text { Di-sy }}$}} \\
\hline & \multicolumn{2}{|l|}{ Omp1 } & \multicolumn{2}{|l|}{ Omp2 } & \multicolumn{2}{|l|}{ Omp3 } & \multicolumn{2}{|l|}{ Omp4 } & \multicolumn{2}{|l|}{ Omp5 } & & & \\
\hline & P4-c & P10-r & P89-r & P97-c & P1-c & P10-r & P153-c & P160-r & P3-r & P6-r & P55 & P59 & P69 \\
\hline$\overline{\mathrm{SiO}_{2}}$ & 53.96 & 53.68 & 54.37 & 54.80 & 54.97 & 54.62 & 54.64 & 55.09 & 54.55 & 54.36 & 51.19 & 53.85 & 53.32 \\
\hline $\mathrm{Al}_{2} \mathrm{O}_{3}$ & 9.45 & 9.46 & 9.60 & 9.74 & 8.93 & 9.19 & 10.20 & 9.98 & 9.66 & 9.83 & 7.73 & 4.07 & 6.03 \\
\hline $\mathrm{TiO}_{2}$ & 0.23 & 0.15 & 0.15 & 0.18 & 0.15 & 0.10 & 0.15 & 0.18 & 0.17 & 0.14 & 0.14 & 0.11 & 0.14 \\
\hline $\mathrm{Cr}_{2} \mathrm{O}_{3}$ & 0.06 & 0.00 & 0.03 & 0.07 & 0.01 & 0.01 & 0.10 & 0.09 & 0.06 & 0.07 & 0.17 & 0.08 & 0.25 \\
\hline $\mathrm{FeO}$ & 3.60 & 3.79 & 3.73 & 3.06 & 4.21 & 4.14 & 2.66 & 3.01 & 3.79 & 2.91 & 4.57 & 3.97 & 3.94 \\
\hline $\mathrm{MnO}$ & 0.07 & 0.00 & 0.03 & 0.04 & 0.06 & 0.03 & 0.07 & 0.03 & 0.05 & 0.07 & 0.11 & 0.14 & 0.00 \\
\hline $\mathrm{MgO}$ & 10.29 & 10.41 & 10.43 & 10.54 & 10.57 & 10.42 & 10.38 & 10.69 & 10.42 & 10.47 & 12.59 & 13.95 & 12.53 \\
\hline $\mathrm{CaO}$ & 16.49 & 16.66 & 16.77 & 16.66 & 16.90 & 16.81 & 16.02 & 16.48 & 16.73 & 16.32 & 19.65 & 22.45 & 20.80 \\
\hline $\mathrm{Na}_{2} \mathrm{O}$ & 5.11 & 5.10 & 5.09 & 5.01 & 4.60 & 4.62 & 5.41 & 4.39 & 4.84 & 4.91 & 2.53 & 1.72 & 2.50 \\
\hline $\mathrm{K}_{2} \mathrm{O}$ & 0.00 & 0.00 & 0.00 & 0.00 & 0.00 & 0.02 & 0.01 & 0.00 & 0.00 & 0.00 & 0.00 & 0.01 & 0.00 \\
\hline Total & 99.25 & 99.25 & 100.19 & 100.10 & 100.38 & 99.95 & 99.65 & 99.93 & 100.28 & 99.08 & 98.68 & 100.35 & 99.51 \\
\hline \multicolumn{14}{|c|}{ Structural formulae on the basis of 6 oxygens } \\
\hline $\mathrm{Si}$ & 1.939 & 1.928 & 1.936 & 1.951 & 1.964 & 1.959 & 1.947 & 1.961 & 1.945 & 1.955 & 1.879 & 1.951 & 1.942 \\
\hline $\mathrm{Al}(\mathrm{IV})$ & 0.061 & 0.072 & 0.064 & 0.049 & 0.036 & 0.041 & 0.053 & 0.039 & 0.055 & 0.045 & 0.121 & 0.049 & 0.058 \\
\hline $\mathrm{Al}(\mathrm{VI})$ & 0.340 & 0.328 & 0.339 & 0.360 & 0.340 & 0.347 & 0.375 & 0.380 & 0.351 & 0.372 & 0.213 & 0.125 & 0.200 \\
\hline $\mathrm{Ti}$ & 0.006 & 0.004 & 0.004 & 0.005 & 0.004 & 0.003 & 0.004 & 0.005 & 0.005 & 0.004 & 0.004 & 0.003 & 0.004 \\
\hline $\mathrm{Cr}$ & 0.002 & 0.000 & 0.001 & 0.002 & 0.000 & 0.000 & 0.003 & 0.002 & 0.002 & 0.002 & 0.005 & 0.002 & 0.007 \\
\hline $\mathrm{Fe}^{3+}$ & 0.063 & 0.091 & 0.068 & 0.023 & 0.006 & 0.011 & 0.041 & 0.000 & 0.027 & 0.006 & 0.076 & 0.037 & 0.020 \\
\hline $\mathrm{Fe}^{2+}$ & 0.045 & 0.023 & 0.043 & 0.068 & 0.120 & 0.113 & 0.038 & 0.090 & 0.086 & 0.082 & 0.058 & 0.083 & 0.100 \\
\hline $\mathrm{Mn}$ & 0.002 & 0.000 & 0.001 & 0.001 & 0.002 & 0.001 & 0.002 & 0.001 & 0.002 & 0.002 & 0.003 & 0.004 & 0.000 \\
\hline $\mathrm{Mg}$ & 0.551 & 0.557 & 0.553 & 0.559 & 0.563 & 0.557 & 0.551 & 0.567 & 0.554 & 0.561 & 0.689 & 0.753 & 0.680 \\
\hline $\mathrm{Ca}$ & 0.635 & 0.641 & 0.640 & 0.636 & 0.647 & 0.646 & 0.612 & 0.628 & 0.639 & 0.629 & 0.773 & 0.871 & 0.812 \\
\hline $\mathrm{Na}$ & 0.356 & 0.355 & 0.351 & 0.346 & 0.318 & 0.321 & 0.373 & 0.303 & 0.335 & 0.342 & 0.180 & 0.121 & 0.177 \\
\hline K & 0.000 & 0.000 & 0.000 & 0.000 & 0.000 & 0.001 & 0.000 & 0.000 & 0.000 & 0.000 & 0.000 & 0.000 & 0.000 \\
\hline Total & 4.000 & 4.000 & 4.000 & 4.000 & 4.000 & 4.000 & 4.000 & 3.975 & 4.000 & 4.000 & 4.000 & 4.000 & 4.000 \\
\hline
\end{tabular}

r: rim; c: core; sy: symplectite; $\mathrm{Fe}^{3+}$ calculated after Ryburn et al. (1976). 


\subsection{Mafic rocks}

The eclogites are fine to medium-grained with grano-nematoblastic textures and consist of garnet + omphacite + phengite + rutile \pm amphibole \pm epidote \pm quart \pm ilmenite \pm chlorite. Late veins consisting of calcite \pm tremolitic amphibole \pm chlorite are sometimes present in the more retrogressed samples and cut across the whole assemblage. Garnet occurs as euhedral crystals $\approx 300-700 \mu \mathrm{m}$ in size in the fine-grained samples and up to $2 \mathrm{~mm}$ in the medium-grained samples (Fig. 3A, B). The latter garnet grains are poikiloblastic crystals with numerous inclusions of quartz, epidote, amphibole, plagioclase, rutile, and ilmenite. In contrast, the smaller crystals are usually devoid of inclusions, apart from opaque minerals. In the more mylonitic microtextural domains, garnet has porphyroclastic features and is associated with abundant recrystallized quartz. Omphacite occurs as subhedral-to-prismatic euhedral crystals. In some fine-grained samples, it is elongated and aligned with epidote, amphibole, and phengite, which together impart a compositional layering and a lineation to the eclogite (Fig. 3B, C). In the partly retrogressed samples and/or sectors of the same rock, omphacite is locally pseudomorphed by symplectitic associations of diopsidic clinopyroxene + plagioclase (Fig. 3A, D). Epidote is mainly present in the fine-grained samples as elongated crystals, and in the more retrogressed sectors it contains inclusions of relic omphacite. Phengitic white mica is present in both wellpreserved eclogites (Fig. 3C) and the retrogressed ones. In the retrogressed samples, a symplectitic association of biotite and plagioclase partly replaces the white mica (Fig. 3E). Amphiboles show a variety of microtextural features: (1) inclusions in porphyroblastic garnet (Fig. 3A); (2) elongated crystals that together with epidote, phengite, and occasionally omphacite have the long dimension oriented along the main foliation (Fig. 3B, C); (3) poikiloblastic crystals containing inclusions of garnet, epidote, and phengite (Fig. $3 \mathrm{~F}$, $\mathrm{G}$ ); and (4) very elongated crystals without orientation and coexisting with chlorite in the late veins (Fig. 3H). Rutile is locally replaced by ilmenite and/or titanite.

Mineral chemistry was analysed for two samples (RO380 and RC0611), and representative mineral analyses are reported in Tables 1-5. Mineral compositions were obtained using the CAMECA SX100 electron microprobe fitted with four wavelength-dispersive spectrometers at the Centre d'analyses CAMPARIS (CNRS, Paris). Accelerating voltage was $15 \mathrm{kV}$, and the beam current was $40 \mathrm{nA}$ for garnet and $10 \mathrm{nA}$ for the other mineral phases. Natural standards were used for calibration. Structural formulae were calculated on the basis of 12 oxygens for garnet, 6 for pyroxene, 22 for micas, 8 for plagioclase, 12.5 for epidote, 29 for tourmaline, and 23 for amphiboles. Ferrous and ferric iron contents were calculated after Ryburn et al. (1976) for garnet and pyroxene and according to Holland and Blundy (1994) and the THERMOCALC AX-program (Holland and Powell, 1998) for amphiboles and epidotes, respectively. B cations in tourmaline were calculated on the basis of stoichiometry. The Leake et al. (1997) nomenclature and subsequent revisions by Hawthorne and Oberti (2007) were used for amphiboles.

Garnet is a pyrope-grossular-rich almandine, and it shows a wide range in composition: almandine $37-54 \%$, pyrope $6-39 \%$, grossular $18-33 \%$, spessartine $1-4 \%$, andradite $0-4 \%$ (Fig. 4 ). The garnet occurs in a range of microtextural environments and either exhibits zoning (Figs. 4, and 5A, B) or is roughly homogeneous (Fig. 5C). The garnet zoning pattern can be broken down into three regions: core, mantle, and rim. In Fig. 4, it is shown that core compositions plot mainly in the C field of Coleman et al. (1965), whereas rim compositions are in the B field. Prograde zoning was found in poikiloblastic euhedral garnet of a medium-grained eclogite that does not show evidence of subsequent dynamic recrystallization (Sample RC0611). These grains show a continuous increase of pyrope $\left[\mathrm{X}_{\mathrm{Mg}}=\mathrm{Mg} /\left(\mathrm{Mg}+\mathrm{Fe}^{2+}+\mathrm{Mn}+\mathrm{Ca}\right)=0.09-0.37\right]$ from core through mantle to rim, a decrease of spessartine $\left[\mathrm{X}_{\mathrm{Mn}}=\mathrm{Mn}\right.$ / $\left.\left(\mathrm{Mg}+\mathrm{Fe}^{2+}+\mathrm{Mn}+\mathrm{Ca}\right)=0.04-0.02\right]$ from core to mantle and a constant value $(0.01)$ from mantle to rim (Fig. 4 A, Table 1$). \mathrm{X}_{\mathrm{Ca}}\left[\mathrm{Ca} /\left(\mathrm{Mg}+\mathrm{Fe}^{2+}+\right.\right.$

Table 3

Representative amphibole analyses for eclogite.

\begin{tabular}{|c|c|c|c|c|c|c|c|c|c|c|c|c|c|c|c|}
\hline \multirow[t]{2}{*}{ Sample } & \multicolumn{5}{|l|}{ RC611 } & \multicolumn{10}{|l|}{ RO380 } \\
\hline & In Grt & In Grt & In Grt & In sy & In kel & Matrix & Matrix & Matrix & Matrix & Matrix & Porphyr & In kel & In cleav & Veins & Veins \\
\hline No. & P103 & P147 & P53 & P80 & P84 & P156 & P11 & P25 & P35 & P14 & P155 & P17 & P10 & P43 & $\mathrm{P} 4$ \\
\hline$\overline{\mathrm{SiO}_{2}}$ & 43.39 & 39.16 & 44.39 & 46.48 & 45.30 & 48.28 & 48.66 & 49.00 & 47.35 & 47.96 & 47.20 & 38.35 & 50.28 & 52.47 & 51.12 \\
\hline $\mathrm{Al}_{2} \mathrm{O}_{3}$ & 18.76 & 20.60 & 14.88 & 13.32 & 12.73 & 13.03 & 13.14 & 13.08 & 13.05 & 13.27 & 13.42 & 21.52 & 10.14 & 3.22 & 4.21 \\
\hline $\mathrm{TiO}_{2}$ & 0.40 & 0.00 & 0.78 & 0.38 & 0.51 & 0.48 & 0.52 & 0.38 & 0.44 & 0.45 & 0.44 & 0.03 & 0.55 & 0.46 & 0.04 \\
\hline $\mathrm{Cr}_{2} \mathrm{O}_{3}$ & 0.07 & 0.22 & 0.02 & 0.05 & 0.13 & 0.08 & 0.00 & 0.02 & 0.03 & 0.02 & 0.09 & 0.08 & 0.13 & 0.00 & 0.00 \\
\hline $\mathrm{FeO}$ & 10.10 & 14.47 & 9.53 & 8.63 & 10.58 & 7.58 & 6.52 & 6.76 & 6.52 & 6.55 & 8.19 & 15.76 & 6.88 & 13.13 & 14.05 \\
\hline $\mathrm{MnO}$ & 0.04 & 0.12 & 0.04 & 0.00 & 0.04 & 0.02 & 0.00 & 0.00 & 0.02 & 0.02 & 0.08 & 0.16 & 0.02 & 0.27 & 0.26 \\
\hline $\mathrm{MgO}$ & 11.65 & 8.48 & 13.01 & 14.44 & 13.34 & 15.20 & 15.72 & 15.23 & 15.41 & 15.42 & 14.39 & 7.96 & 16.41 & 14.95 & 14.03 \\
\hline $\mathrm{CaO}$ & 9.87 & 11.67 & 9.83 & 10.52 & 11.71 & 9.67 & 9.67 & 9.61 & 9.64 & 9.68 & 10.52 & 10.81 & 11.02 & 12.68 & 12.20 \\
\hline $\mathrm{Na}_{2} \mathrm{O}$ & 3.45 & 1.98 & 2.98 & 2.82 & 1.91 & 2.49 & 3.32 & 3.06 & 3.41 & 3.39 & 2.52 & 2.37 & 2.06 & 0.16 & 0.26 \\
\hline $\mathrm{K}_{2} \mathrm{O}$ & 0.48 & 1.68 & 0.83 & 0.74 & 0.96 & 0.64 & 0.65 & 0.66 & 0.62 & 0.71 & 0.57 & 0.20 & 0.42 & 0.17 & 0.08 \\
\hline Total & 98.21 & 98.37 & 96.31 & 97.39 & 97.20 & 97.46 & 98.20 & 97.79 & 96.49 & 97.48 & 97.42 & 97.26 & 97.91 & 97.52 & 96.25 \\
\hline \multicolumn{16}{|c|}{ Structural formulae on the basis of 23 oxygens } \\
\hline $\mathrm{Si}$ & 6.180 & 5.755 & 6.416 & 6.621 & 6.576 & 6.744 & 6.771 & 6.844 & 6.725 & 6.745 & 6.684 & 5.603 & 7.029 & 7.570 & 7.486 \\
\hline $\mathrm{Al}(\mathrm{IV})$ & 1.820 & 2.245 & 1.584 & 1.379 & 1.424 & 1.256 & 1.229 & 1.156 & 1.275 & 1.255 & 1.316 & 2.397 & 0.971 & 0.430 & 0.514 \\
\hline $\mathrm{Al}(\mathrm{VI})$ & 1.330 & 1.324 & 0.952 & 0.859 & 0.754 & 0.889 & 0.927 & 0.998 & 0.911 & 0.946 & 0.926 & 1.309 & 0.701 & 0.118 & 0.213 \\
\hline $\mathrm{Ti}$ & 0.043 & 0.000 & 0.085 & 0.041 & 0.056 & 0.050 & 0.054 & 0.040 & 0.047 & 0.047 & 0.047 & 0.003 & 0.058 & 0.050 & 0.004 \\
\hline $\mathrm{Cr}$ & 0.008 & 0.026 & 0.002 & 0.006 & 0.015 & 0.008 & 0.000 & 0.002 & 0.003 & 0.002 & 0.010 & 0.009 & 0.014 & 0.000 & 0.000 \\
\hline $\mathrm{Fe}^{3+}$ & 0.218 & 0.341 & 0.424 & 0.309 & 0.188 & 0.574 & 0.301 & 0.253 & 0.281 & 0.242 & 0.301 & 0.980 & 0.204 & 0.215 & 0.309 \\
\hline $\mathrm{Fe}^{2+}$ & 0.985 & 1.437 & 0.729 & 0.720 & 1.097 & 0.311 & 0.458 & 0.537 & 0.494 & 0.529 & 0.669 & 0.946 & 0.600 & 1.370 & 1.412 \\
\hline $\mathrm{Mn}$ & 0.005 & 0.015 & 0.005 & 0.000 & 0.005 & 0.003 & 0.000 & 0.000 & 0.002 & 0.002 & 0.010 & 0.020 & 0.003 & 0.034 & 0.032 \\
\hline $\mathrm{Mg}$ & 2.473 & 1.857 & 2.802 & 3.066 & 2.886 & 3.164 & 3.260 & 3.170 & 3.262 & 3.232 & 3.038 & 1.733 & 3.420 & 3.214 & 3.062 \\
\hline $\mathrm{Ca}$ & 1.506 & 1.838 & 1.523 & 1.606 & 1.821 & 1.448 & 1.441 & 1.438 & 1.467 & 1.459 & 1.596 & 1.692 & 1.651 & 1.961 & 1.914 \\
\hline $\mathrm{Na}$ & 0.953 & 0.564 & 0.835 & 0.778 & 0.537 & 0.674 & 0.897 & 0.829 & 0.939 & 0.925 & 0.692 & 0.671 & 0.557 & 0.045 & 0.074 \\
\hline K & 0.087 & 0.315 & 0.154 & 0.134 & 0.178 & 0.113 & 0.115 & 0.118 & 0.112 & 0.127 & 0.103 & 0.037 & 0.075 & 0.031 & 0.015 \\
\hline Total & 15.608 & 15.717 & 15.512 & 15.518 & 15.536 & 15.236 & 15.453 & 15.385 & 15.519 & 15.511 & 15.390 & 15.401 & 15.284 & 15.036 & 15.035 \\
\hline
\end{tabular}

sy: symplectite; kel: kelyphite; porphyr: porphyroblastic; cleav: cleavage; $\mathrm{Fe}^{3+}$ calculated after Holland and Blundy (1994). 
Table 4

Representative white mica, biotite, plagioclase and epidote analyses for eclogite.

\begin{tabular}{|c|c|c|c|c|c|c|c|c|c|c|c|c|c|c|c|c|}
\hline \multirow{3}{*}{$\begin{array}{l}\text { Sample } \\
\text { No. }\end{array}$} & \multicolumn{6}{|l|}{ RC611 } & \multicolumn{10}{|l|}{ RO380 } \\
\hline & In Grt & Matrix & Matrix & In sy & In sy & In sy & Matrix & Matrix & Matrix & Matrix & Matrix & Matrix & In sy & In sy & Matrix & Matrix \\
\hline & WmP51 & WmP3 & $\mathrm{WmP} 4$ & BtP5 & BtP6 & PlP7 & WmP165 & WmP168 & WmP168-r & WmP171 & WmP11 & $\mathrm{WmP} 12$ & PIP34 & BtP40 & EpP44 & EpP150 \\
\hline$\overline{\mathrm{SiO}_{2}}$ & 47.95 & 50.50 & 49.01 & 37.78 & 38.00 & 63.09 & 49.48 & 50.19 & 49.58 & 50.70 & 51.30 & 50.69 & 64.90 & 37.10 & 39.56 & 39.57 \\
\hline $\mathrm{Al}_{2} \mathrm{O}_{3}$ & 31.53 & 28.10 & 26.96 & 17.70 & 18.05 & 23.83 & 29.29 & 30.15 & 30.08 & 28.52 & 30.10 & 28.88 & 22.92 & 17.75 & 32.22 & 32.71 \\
\hline $\mathrm{TiO}_{2}$ & 0.94 & 0.90 & 0.72 & 1.62 & 1.46 & 0.00 & 0.02 & 0.84 & 0.74 & 0.39 & 0.00 & 0.71 & 0.00 & 3.30 & 0.10 & 0.09 \\
\hline $\mathrm{Cr}_{2} \mathrm{O}_{3}$ & 0.06 & 0.04 & 0.08 & 0.28 & 0.30 & 0.00 & 0.75 & 0.00 & 0.05 & 0.53 & 0.28 & 0.13 & 0.00 & 0.48 & 0.04 & 0.04 \\
\hline $\mathrm{FeO}$ & 1.37 & 1.57 & 2.13 & 11.63 & 11.33 & 0.00 & 1.41 & 1.33 & 1.21 & 1.22 & 1.35 & 1.65 & 0.12 & 12.12 & 1.16 & 1.14 \\
\hline $\mathrm{MnO}$ & 0.07 & 0.00 & 0.05 & 0.00 & 0.04 & 0.00 & 0.01 & 0.00 & 0.00 & 0.05 & 0.02 & 0.00 & 0.00 & 0.19 & 0.00 & 0.00 \\
\hline $\mathrm{MgO}$ & 2.67 & 4.01 & 4.79 & 15.11 & 15.62 & 0.00 & 3.45 & 3.14 & 3.03 & 4.05 & 1.69 & 3.74 & 0.00 & 13.91 & 0.08 & 0.06 \\
\hline $\mathrm{CaO}$ & 0.00 & 0.04 & 0.19 & 0.05 & 0.00 & 4.50 & 0.02 & 0.00 & 0.00 & 0.03 & 0.00 & 0.02 & 3.25 & 0.05 & 23.82 & 23.78 \\
\hline $\mathrm{Na}_{2} \mathrm{O}$ & 0.93 & 0.37 & 0.37 & 0.12 & 0.00 & 9.55 & 0.47 & 0.54 & 0.53 & 0.32 & 0.30 & 0.36 & 10.04 & 0.06 & 0.04 & 0.02 \\
\hline $\mathrm{K}_{2} \mathrm{O}$ & 7.60 & 8.58 & 8.68 & 9.33 & 9.98 & 0.19 & 8.41 & 8.42 & 9.05 & 7.82 & 10.07 & 8.03 & 0.12 & 9.18 & 0.01 & 0.01 \\
\hline Total & 93.12 & 94.10 & 92.97 & 93.62 & 94.78 & 101.17 & 93.30 & 94.60 & 94.26 & 93.63 & 95.12 & 94.20 & 101.34 & 94.13 & 97.03 & 97.42 \\
\hline \multicolumn{17}{|c|}{ Structural formulae on the basis of 22, 8 and 12.5 oxygens for micas, plagioclase and epidote respectively } \\
\hline $\mathrm{Si}$ & 6.430 & 6.724 & 6.659 & 5.617 & 5.588 & 2.762 & 6.635 & 6.627 & 6.598 & 6.741 & 6.777 & 6.714 & 2.826 & 5.511 & 3.026 & 3.013 \\
\hline $\mathrm{Al}(\mathrm{IV})$ & 1.570 & 1.276 & 1.341 & 2.383 & 2.412 & 1.230 & 1.365 & 1.373 & 1.402 & 1.259 & 1.223 & 1.286 & 1.177 & 2.489 & & \\
\hline $\mathrm{Al}(\mathrm{VI})$ & 3.413 & 3.133 & 2.976 & 0.718 & 0.716 & 0.000 & 3.264 & 3.319 & 3.315 & 3.211 & 3.463 & 3.222 & 0.000 & 0.000 & 2.906 & 2.936 \\
\hline $\mathrm{Ti}$ & 0.095 & 0.090 & 0.073 & 0.181 & 0.162 & 0.000 & 0.075 & 0.083 & 0.074 & 0.039 & 0.000 & 0.070 & 0.000 & 0.619 & 0.006 & 0.005 \\
\hline $\mathrm{Cr}$ & 0.006 & 0.004 & 0.009 & 0.033 & 0.034 & 0.003 & 0.003 & 0.000 & 0.006 & 0.056 & 0.030 & 0.014 & 0.000 & 0.056 & 0.002 & 0.002 \\
\hline $\mathrm{Fe}^{3+}$ & & & & & & & & & & & & & & & 0.073 & 0.072 \\
\hline $\mathrm{Fe}^{2+}$ & 0.154 & 0.174 & 0.241 & 1.445 & 1.394 & 0.000 & 0.158 & 0.147 & 0.135 & 0.136 & 0.150 & 0.182 & 0.000 & 1.505 & 0.001 & 0.001 \\
\hline Mn & 0.008 & 0.000 & 0.006 & 0.000 & 0.004 & 0.000 & 0.001 & 0.000 & 0.000 & 0.005 & 0.002 & 0.000 & 0.000 & 0.024 & 0.000 & 0.000 \\
\hline $\mathrm{Mg}$ & 0.533 & 0.796 & 0.971 & 3.348 & 3.423 & 0.000 & 0.689 & 0.617 & 0.600 & 0.803 & 0.333 & 0.739 & 0.000 & 3.080 & 0.008 & 0.006 \\
\hline $\mathrm{Ca}$ & 0.000 & 0.005 & 0.028 & 0.007 & 0.000 & 0.211 & 0.002 & 0.000 & 0.000 & 0.004 & 0.000 & 0.002 & 0.152 & 0.009 & 1.952 & 1.940 \\
\hline $\mathrm{Na}$ & 0.242 & 0.096 & 0.097 & 0.034 & 0.000 & 0.811 & 0.122 & 0.138 & 0.136 & 0.081 & 0.077 & 0.092 & 0.848 & 0.018 & 0.006 & 0.003 \\
\hline K & 1.301 & 1.458 & 1.505 & 1.770 & 1.872 & 0.011 & 1.439 & 1.418 & 1.536 & 1.326 & 1.697 & 1.356 & 0.006 & 1.739 & 0.001 & 0.001 \\
\hline Total & 13.752 & 13.757 & 13.906 & 15.537 & 15.605 & 5.028 & 13.754 & 13.722 & 13.802 & 13.661 & 13.752 & 13.679 & 5.009 & 15.049 & 7.981 & 7.979 \\
\hline
\end{tabular}

sy: symplectite.

$\mathrm{Mn}+\mathrm{Ca})]$ is constant from core to mantle and decreases only near the $\operatorname{rim}(0.33$ to 0.18 from core to $\mathrm{rim}) . \mathrm{X}_{\mathrm{Fe}}\left[\mathrm{Fe} /\left(\mathrm{Mg}+\mathrm{Fe}^{2+}+\mathrm{Mn}+\mathrm{Ca}\right)\right]$ shows a higher content in the core $\left(\mathrm{X}_{\mathrm{Fe}} \approx 0.54\right)$ compared with the mantle and $\operatorname{rim}\left(\mathrm{X}_{\mathrm{Fe}} \approx 0.41\right)$. More complex zoning was detected in subhedral crystals that grew dynamically and in equilibrium with omphacite, amphibole, and epidote (Sample RO380). In this garnet

Table 5

Representative garnet, white mica, biotite, plagioclase and tourmaline analyses for host pelitic schist.

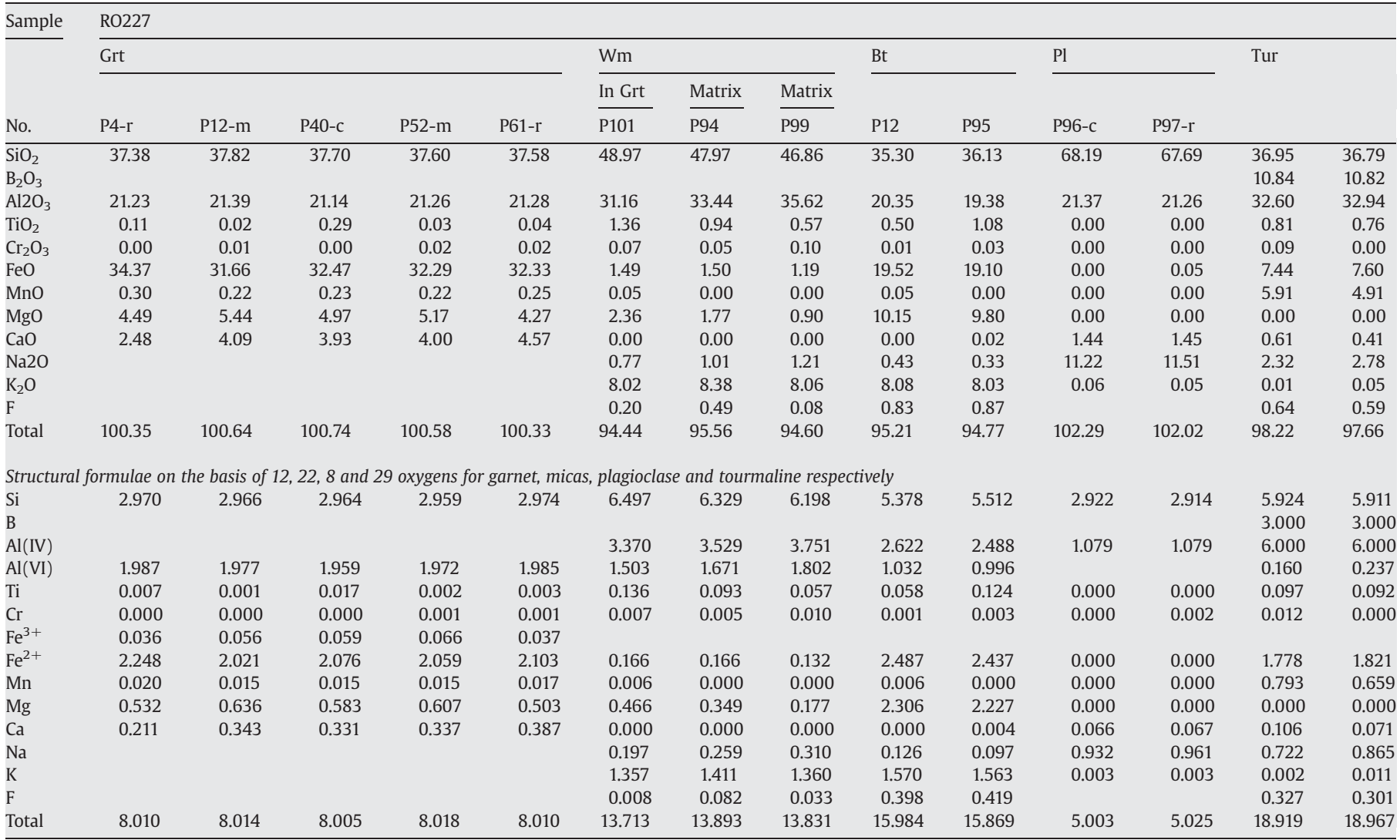

r: rim; m: mantle; c: core. 


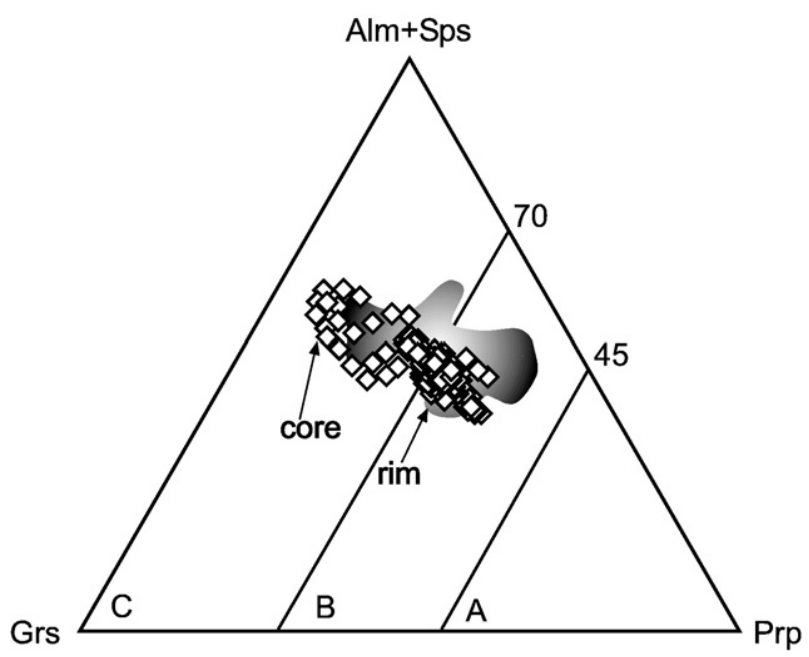

Fig. 4. Garnet ternary diagram after Coleman et al. (1965). Plotted data refer to garnets from the Collingwood River eclogite samples. Garnet compositions from Northern Victoria Land (Antarctica) (Di Vincenzo et al., 1997) are shown for comparison (grey area). End members are almandine + spessartine (Alm + Sps), grossular (Grs), and pyrope (Prp). Fields A, B, and C represent the compositional variations of garnets in eclogites associated with kimberlites and peridotites (A), gneiss (B), and blueschist (C). Garnets from Antarctica partly overlap with those of Tasmania. However, the core compositions of garnet from Tasmania lie in the $\mathrm{C}$ field, whereas the rims are mainly in the B field. The opposite is reported for garnets from Antarctica.

(Fig. 5B), zoning is characterized by a low and homogeneous $\mathrm{X}_{\mathrm{Mn}}$ content $(\approx 0.01)$, and $\mathrm{X}_{\mathrm{Mg}}$ shows high values in the core region $\left(X_{M g}=0.29-0.32\right)$, a decrease in the mantle $\left(X_{M g}=0.27-0.23\right)$, and a subsequent increase in the rim region $\left(\mathrm{X}_{\mathrm{Mg}}=0.30-0.38\right)$. Finally, porphyroclastic garnet, in the microtextural occurrences characterized by mylonitic deformation, has, apart from very narrow rims, a nearly homogeneous composition, with $\mathrm{X}_{\mathrm{Mg}} \approx 0.30-0.35, \mathrm{X}_{\mathrm{Mn}} \approx 0.01$, $\mathrm{X}_{\mathrm{Fe}} \approx 0.42$, and $\mathrm{X}_{\mathrm{Ca}} \approx 0.20-0.25$ (Fig. $5 \mathrm{C}$ ).

Omphacite is unzoned, with a jadeite component of $27-35 \mathrm{~mol} \%$, acmite $0-9 \%$, and diopside component of $49-56 \%$ (Fig. 6). Diopsidic pyroxene $\left(\mathrm{X}_{\mathrm{jd}}\right.$ up to $0.16, \mathrm{X}_{\mathrm{di}}$ up to 0.81$)$, together with an albitic plagioclase ( $\mathrm{X}_{\mathrm{ab}}$ up to 0.82 ), is present in the symplectite that replaces omphacite. In the rocks in which omphacite is totally replaced by symplectite, a rough estimate of $\mathrm{X}_{\mathrm{jd}}$ was calculated on the basis of the volume percentages in symplectite of plagioclase $(\approx 30 \%)$ and of the diopsidic clinopyroxene $(\approx 70 \%)$. The estimated jadeite content is similar to the composition of well-preserved omphacite $\left(\mathrm{X}_{\mathrm{Jd}} \approx 0.33\right)$.

White mica in equilibrium with omphacite and garnet is a phengite with $\mathrm{Si}^{4+}=6.6-6.8$ a. f. u. and $\mathrm{Al}=4.4-5.2$ a.f.u. based on 22 oxygens. An albite-rich plagioclase ( $\mathrm{X}_{\mathrm{ab}}$ up to 0.87 ), together with biotite $\left(\mathrm{X}_{\mathrm{Mg}} \approx 0.67\right)$, replaced phengite during retrogression. White mica included in garnet has a lower $\mathrm{Si}^{4+}$ content $(\approx 6.4$ a.f.u. based on 22 oxygens).

Amphibole shows different compositions (barroisite, Mg-katophorite, tschermakite, pargasite, edenite, Mg-hornblende, and actinolite) in the different microtextural settings (Fig. 7). High Al Ca-amphiboles (pargasite) enclosed in prograde garnet were the first to form, and they constitute a group around the pargasite end member in Fig. 7. Nematoblasts or poikiloblasts of $\mathrm{Na}-\mathrm{Ca}$ amphiboles, associated with omphacite, garnet, and phengite, plot below the ideal barroisite end member in Fig. 7. Ca-amphiboles present as coronas around garnet are Al rich and plot near the pargasite end member (Fig. 7), together with the amphiboles enclosed in garnet. In contrast, Ca-amphiboles associated with the symplectitic minerals (diopside + plagioclase) after omphacite have lower $\mathrm{Al}$ and $\mathrm{Na}$ contents than the $\mathrm{Na}-\mathrm{Ca}$ amphiboles, and together with late actinolite or low $\mathrm{Al}^{\mathrm{IV}} \mathrm{Mg}$-hornblende they define a trend along the barroisite-tremolite ideal joint. The different microtextural and chemical types of amphiboles are probably linked to the different stages in the equilibration of the rock.

The epidote group mineral is zoisite.

For comparison, in Figs. 4, 6, and 7 the mineral composition of garnet, omphacite, and amphibole of eclogites from the Lanterman

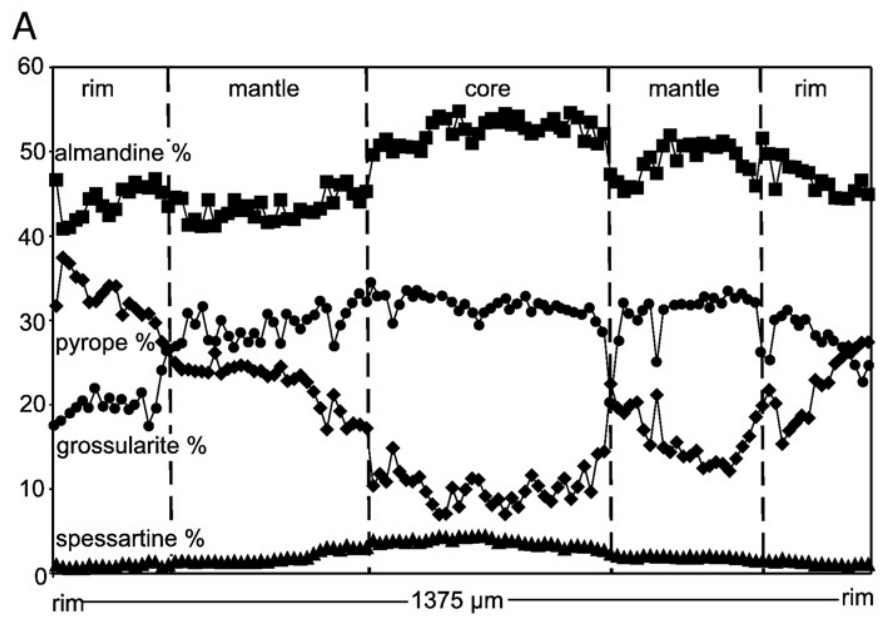

B

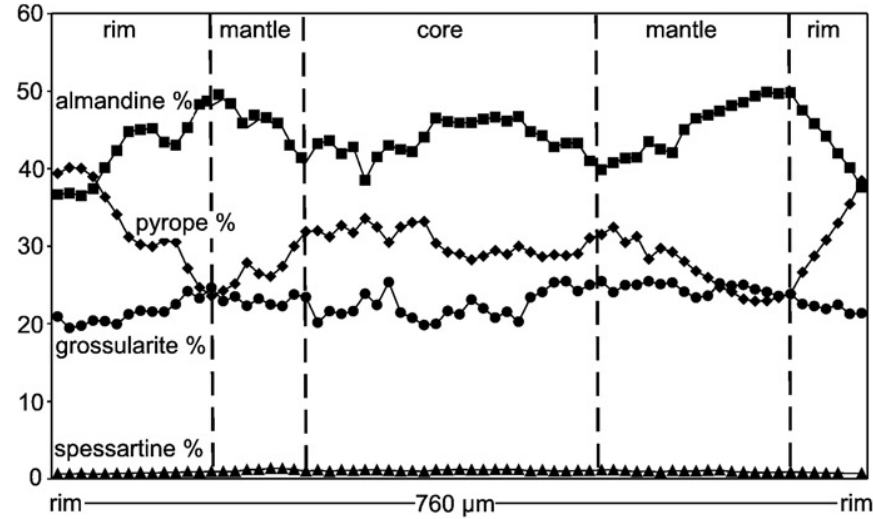

C

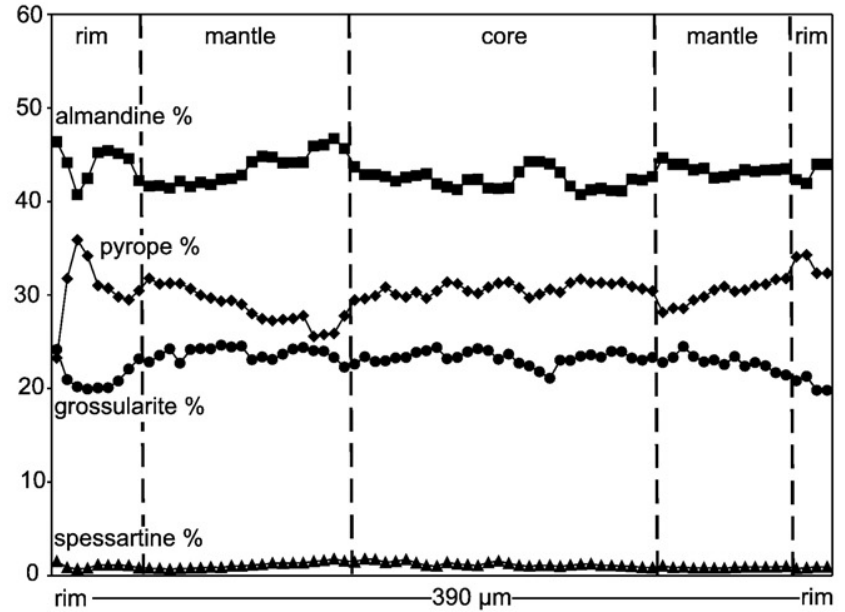

Fig. 5. Chemical zonation of different types of garnet in terms of the almandine $\left(100 \times \mathrm{X}_{\mathrm{Fe}}\right)$, pyrope $\left(100 \times \mathrm{X}_{\mathrm{Mg}}\right)$, grossular $\left(100 \times \mathrm{X}_{\mathrm{Ca}}\right)$, and spessartine $\left(100 \times \mathrm{X}_{\mathrm{Mn}}\right)$ end members. Note the different profiles for pyrope, grossular, and spessartine in the different microtextural occurrences of garnet. Profile (A) refers to large porphyroblastic garnet, profile (B) refers to small recrystallized garnet, and profile (C) refers to relics in mylonitized portions of the rock. 


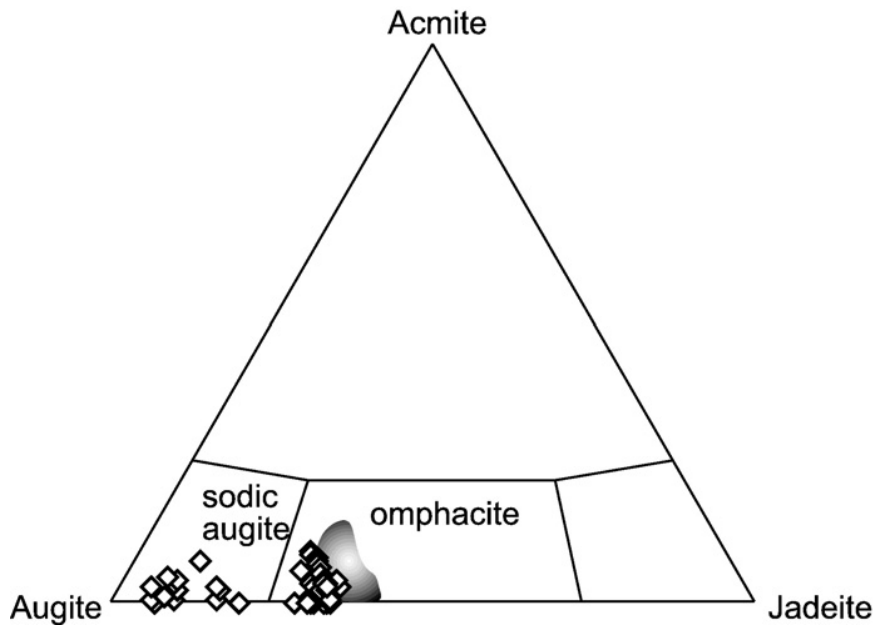

Fig. 6. Pyroxene composition diagram (Essene and Fyfe, 1967). Plotted data are pyroxene from the Collingwood River eclogite samples and from Northern Victoria Land (Antarctica) (Di Vincenzo et al., 1997). Omphacites from Antarctica are more jadeite rich than those from Tasmania. Representative points in the sodic augite field refer to clinopyroxene in the symplectite after omphacite.

Range (Northern Victoria Land, Antarctica) are also reported (Di Vincenzo et al., 1997; Di Vincenzo and Palmeri, 2001). It is worth noting the opposite zoning from core to rim in the garnets, the higher jadeitic component of omphacite, and the higher Na content for NaCa amphiboles of the eclogites from Antarctica compared with those from Tasmania.

\subsection{Host schists}

The schist of the Franklin Metamorphic Complex exposed in the Collingwood River basin consists of fine-grained quartz + white mica + plagioclase + garnet \pm biotite \pm kyanite \pm fibrolitic sillimanite, with accessory tourmaline, rutile, ilmenite, apatite, and zircon. They are characterized by white mica \pm biotite arranged in a grano-lepidoblastic texture that defines the main foliation. The latter is a syn-mylonitic foliation that wraps around the large garnets, but in some samples smaller garnets \pm kyanite relics together with micas are observed.

Garnet grains range in sizes from $100 \mu \mathrm{m}$ to $2 \mathrm{~mm}$ and are euhedral to anhedral. The biggest garnets are fractured and locally contain inclusions of quartz, rutile, white mica, biotite, and ilmenite (Fig. 8A). The smallest crystals of garnet are devoid of inclusions and are located along the main foliation (Fig. 8B). Kyanite is usually anhedral with resorbed margins and is always enclosed in large, white mica flakes (Fig. 8C). Rare wisp-like needles of sillimanite are present at the contact between quartz and/or plagioclase with white mica (Fig. 8D). In the samples in which kyanite is abundant, biotite is rare and consists of very small flakes at the rim of garnet or associated with tourmaline.

Microprobe analyses (Table 5) were performed on garnet, biotite, white mica, plagioclase and tourmaline for the sample (RO 227), which is characterized by a mylonitic foliation with small garnets (up to $100 \mu \mathrm{m}$ ), relicts of kyanite, and rare fibrolitic sillimanite. Garnet is a nearly homogeneous almandine $\left(\mathrm{X}_{\mathrm{Fe}}=0.66-0.83\right)$ with a significant pyrope $\left(X_{\mathrm{Mg}}=0.10-0.20\right)$ and a grossular component $\left(\mathrm{X}_{\mathrm{Ca}}=0.05-0.10\right)$, while the spessartine component is very low $\left(\mathrm{X}_{\mathrm{Mn}}=0.006\right)$. Zoning (Fig. 9$)$ is present only at the extreme rim, and it is characterized by a decrease of pyrope and grossular components and by an increase in almandine.

White mica is an Al-muscovite with low $\mathrm{Si}^{4+}=6.2-6.5$ (a.f.u. based on 22 oxygens); the highest values have been found in white mica inclusions in garnet or at the core of large flakes.
Plagioclase is a homogeneous albite $\left(\mathrm{X}_{\mathrm{ab}}=0.91-0.95\right)$, with the highest value corresponding to plagioclase enclosed within garnet as polycrystalline inclusions together with white mica.

Biotite is compositionally homogeneous with $\mathrm{X}_{\mathrm{Mg}}=0.45-0.48$, and tourmaline has a dravite-rich component $\left(\mathrm{X}_{\mathrm{Mg}}=0.69-0.73\right)$.

\section{Metamorphic evolution of the Tasmanian high-pressure rocks}

\subsection{Mafic rocks}

Garnet compositional zoning and its inclusions and various microtextural features are essential to the reconstruction of the individual stages of the metamorphic evolution and of the corresponding $P-T$ conditions of eclogites. The prograde zoned garnet nucleated and crystallized early in the development of the eclogite facies assemblage, as indicated by the lack of omphacite inclusions. In addition, the preservation of the prograde growth zoning is, according to Tracy (1982), indicative that the minimum temperature $\left(\approx 650{ }^{\circ} \mathrm{C}\right)$ for significant volume diffusion was not overstepped.

Six main stages of mineral growth are distinguished based on the garnet zoning and its mineral inclusions, together with the different microtextural and chemical features of the mineral phases.

Stage I is represented by the formation of the porphyroblastic garnet cores, low in pyrope but high in grossular and spessartine components. This combination has been detected in large euhedral crystals in which small inclusions of quartz and plagioclase $\left(\mathrm{X}_{\mathrm{ab}} \approx\right.$ 0.88 ) have been found. The compositional peculiarity of garnet and the mineral inclusions suggests a greenschist/amphibolite-facies metamorphism for this stage.

Stage II is represented by the mantle zone of large euhedral crystals of garnet or by the core of recrystallized subhedral grains, which have a steadily increasing pyrope and constant grossular contents, as well as the abundant inclusions of quartz, plagioclase, and, pargasite \pm white mica $\left(\mathrm{Si}^{4+}\right.$ up to 6.4 a.f.u.) \pm epidote. The nature of the inclusions and the garnet zoning are indicative

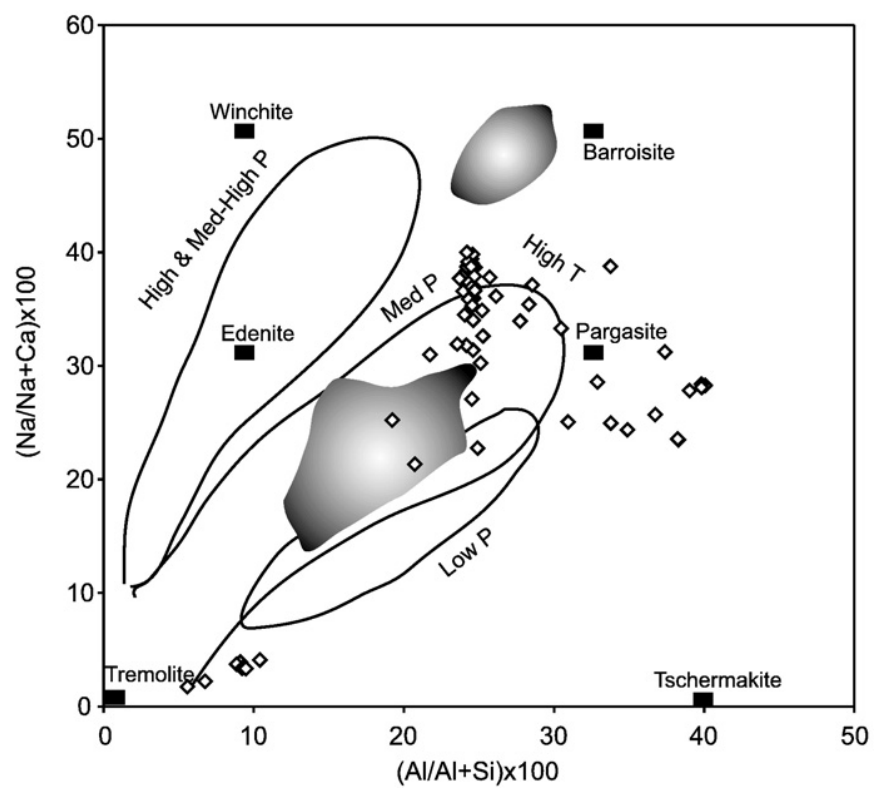

Fig. 7. Variation in composition of amphibole in terms of $100 \times \mathrm{Na} /(\mathrm{Na}+\mathrm{Ca})$ versus $100 \times \mathrm{Al} /(\mathrm{A}+\mathrm{Si})$. Plotted data are amphiboles from the Collingwood River eclogite samples (squares) and grey areas refer to Northern Victoria Land (Antartica) (Di Vincenzo and Palmeri, 2001). Compositional fields of amphiboles from different metamorphic series are from (Laird and Albee, 1981). 

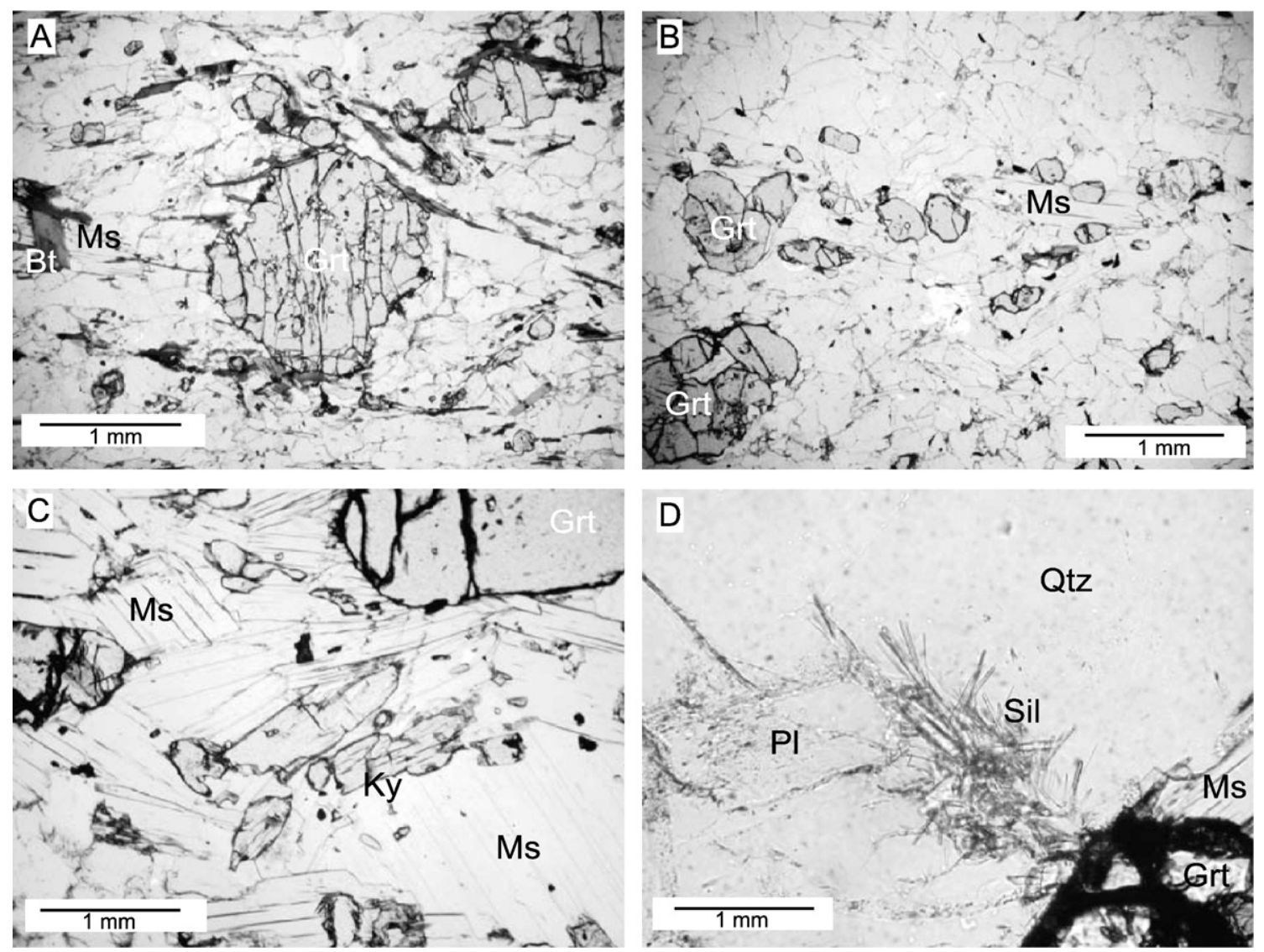

Fig. 8. Photomicrographs of microstructures from hosting schists, Collingwood River (Tasmania). Mineral symbols after Kretz (1983). (A) Porphyroblastic garnet with inclusions wrapped around by the dominant foliation defined by muscovite and biotite. One nicol, sample RC0620. (B) Small garnets together with biotite and muscovite along the dominant foliation. One nicol, sample RO227. (C) Kyanite relics within large flakes of secondary muscovite. One nicol, sample RO227. (D) Fibrolitic sillimanite at the contact between plagioclase and quartz. Muscovite and garnet are also present. One nicol, sample RO227.

of an amphibolite-facies metamorphism. The reaction R1 in Fig. 10 (Plyusnina, 1982),

Chlorite + plagioclase + quartz + calcite

$=$ hornblende + zoisite $+\mathrm{CO}_{2}+\mathrm{H}_{2} \mathrm{O}$,

explains the presence of Ca-amphiboles and epidote as inclusions in garnet, as well as the lack of chlorite.

Stage III probably represents the peak metamorphic conditions. The rims of garnet in both recrystallized grains and the large euhedral crystals show the maximum pyrope content and the lowest grossular value. Inclusions in the rims are less common than in the mantle, except for rutile. Rims of garnet grew with matrix omphacite, phengite, and $\mathrm{Na}-\mathrm{Ca}$ amphiboles, and together they define the eclogite facies stage. The transition from the amphibolite-facies (stage II) to the eclogite facies (stage III) can be described through the overstepping of three model reactions (Fig. 10)

Albite $=$ jadeite + quartz (Holland, 1983),

the dehydration reaction

$\mathrm{Ca}-$ amphibole + plagioclase + quartz

$=$ garnet + omphacite $+\mathrm{H}_{2} \mathrm{O}$ (Banno et al., 2000),

and

Muscovite + diopside $=$ celadonite + pyrope

+ grossular (Waters and Martin, 1993).

The products of these three reactions describe the main assemblage of the eclogite facies stage III, while the reactants are phases found as inclusions in garnet.
With regard to stages IV and V, many microtextural and mineral compositional features are indicative of these stages: (1) small resorbed garnets characterized by a nearly homogeneous composition that can be enclosed as relics in porphyroblastic Ca-amphiboles or in domains of late mylonitic recrystallization, (2) symplectitic association of albitic plagioclase + diopsidic clinopyroxene after omphacite, (3) symplectitic association of plagioclase + biotite after phengite, (4) Ca-amphibole + plagioclase coronas around garnet, and (5) amphibole + plagioclase symplectite at the rims of plagioclase + diopside symplectite. These microtextural features formed under amphibolitefacies conditions during a continuous decrease of pressure. In particular, the symplectitic associations after omphacite and phengite define

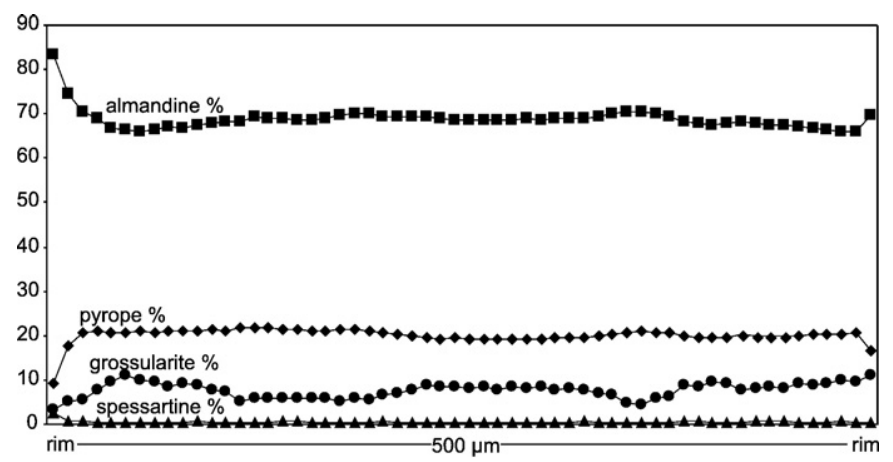

Fig. 9. Chemical zonation of garnets from pelitic schist hosting the eclogite from the Collingwood River in terms of the almandine $\left(100 \times \mathrm{X}_{\mathrm{Fe}}\right)$ pyrope $\left(100 \times \mathrm{X}_{\mathrm{Mg}}\right)$, grossular $\left(100 \times \mathrm{X}_{\mathrm{Ca}}\right)$ and spessartine $\left(100 \times \mathrm{X}_{\mathrm{Mn}}\right)$ end members. 


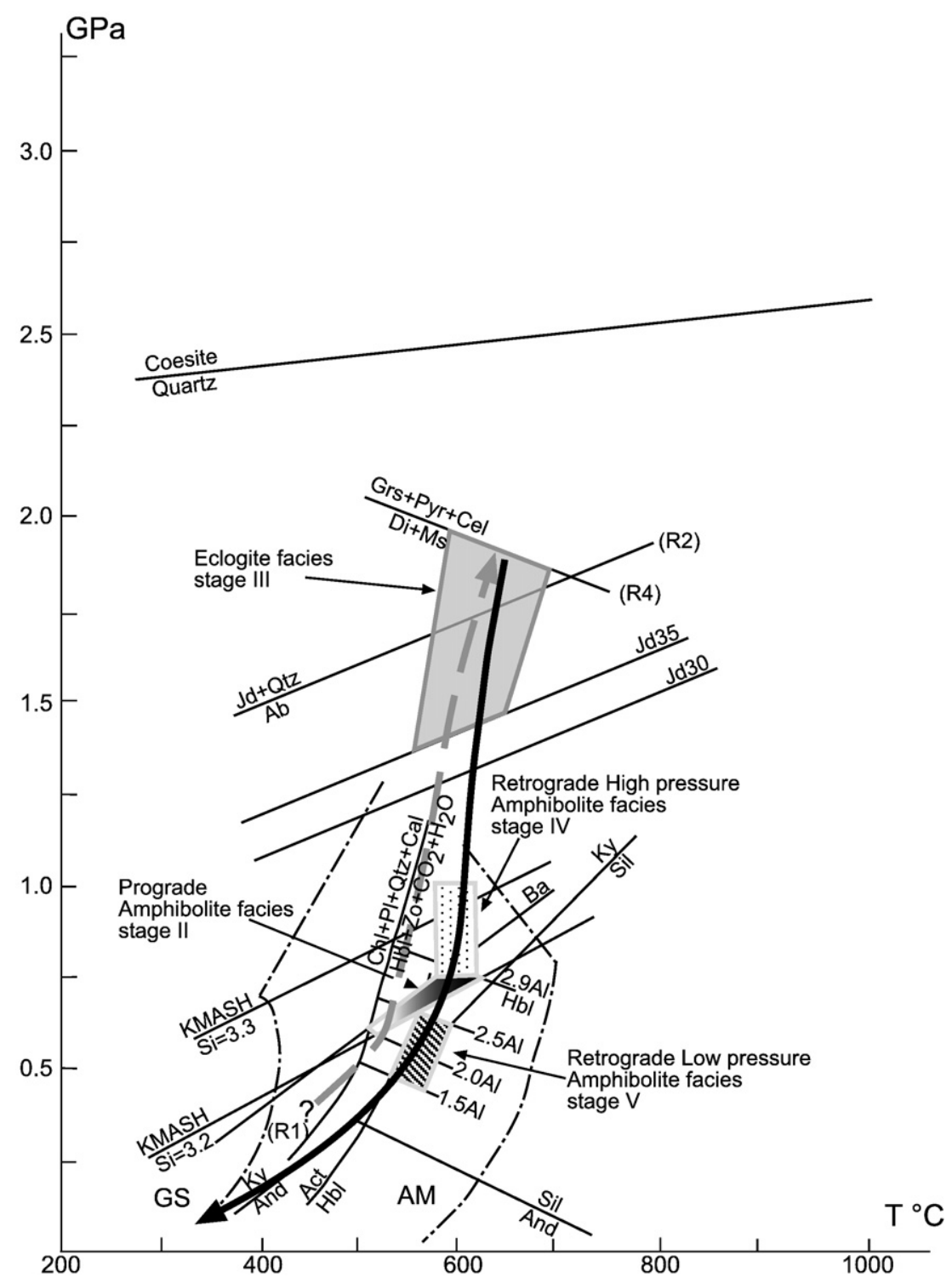

Fig. 10. Prograde (dashed grey arrow) and retrograde $P-T$ path (thick black arrow) for the eclogite from the Collingwood River (Tasmania). Question mark (?) refers to the unconstrained stage I. Coesite-quartz curve after Bohlen and Boettcher (1982); Ab = Jd + Qtz and jadeite isopleth (Jd 30$)$ are after Holland (1983). Di + Ms $=\mathrm{Grs}+$ Prp + Cel is after Waters and Martin (1993); $\mathrm{Chl}+\mathrm{Pl}+\mathrm{Qtz}=\mathrm{Hbl}+\mathrm{Zo}+\mathrm{CO}_{2}+\mathrm{V}$ and Al tot content of hornblende are after Plyusnina (1982); aluminium silicate triple-point is according to Holdaway (1971); isopleths of $\mathrm{Si}^{4+}$ content are after Massonne and Schreyer (1987); and barroisite and actinolite stability field are after Ernst (1979). Greenschist-facies (GS) and amphibolite-facies (AM) fields are after Spear (1993). P-T boxes are based on thermobarometric estimates, and mineral symbols are according to Kretz (1983); Phe is phengite, Cel is celadonite, and Ba is barroisite.

the first retrogression into the amphibolite-facies (stage IV), whereas the development of amphibole in the symplectite or kelyphite around garnet continued to develop at lower pressure and temperature (stage $\mathrm{V}$ ).

The main reactions that can describe the transition from the eclogite facies stage III to the amphibolite-facies stages IV and V are:

$\begin{aligned} \mathrm{Na}-\text { clinopyroxene }+ \text { quartz }= & \mathrm{Na}-\text { poorclinopyroxene } \\ & + \text { plagioclase }\end{aligned}$

Phengite + quartz $+\mathrm{Na}+\mathrm{Ca}+\mathrm{Fe}=$ biotite + plagioclase $+\mathrm{K}$

$$
+\mathrm{H}_{2} \mathrm{O} \text { (Klemd et al., 1991), }
$$

Garnet + omphacite $+\mathrm{H}_{2} \mathrm{O}=\mathrm{Ca}-$ amphibole + plagioclase + quartz (Banno et al., 2000),
$\mathrm{Ca}-$ clinopyroxene $+\mathrm{H}_{2} \mathrm{O}=\mathrm{Ca}-$ amphibole + quartz

Stage VI is a greenschist-facies stage marked by the crystallization of tremolite and/or low $\mathrm{Al}^{\mathrm{IV}} \mathrm{Mg}$-hornblende coexisting with chlorite and albitic plagioclase in the late veins.

In conclusion, the metamorphic evolution of eclogites is characterized by a greenschist/amphibolite-facies (stages I and II) before the formation of eclogite (stage III), and the latter is then followed by a decompression into amphibolite-facies (stages IV and V) and a late retrogression to greenschist-facies (stage VI).

\subsection{Host schists}

The assemblages and mineral compositions in these samples of pelitic schist from the Collingwood River basin adjacent to the eclogite 
are indicative of medium-pressure amphibolite-facies without any evidence of a polymetamorphic evolution.

\section{5. $P-T$ conditions of Tasmanian high-pressure rocks}

\subsection{Mafic rocks}

\subsubsection{Stages I and II}

These early stages cannot be constrained through thermobarometric calculations. However, on the basis of the core composition of the large euhedral garnets and the inclusions therein, stage II can be roughly determined (Fig. 10) with reaction (R1), by the Al content of Ca-amphibole (Plyusnina, 1982), the actinolite-hornblende and barroisite stability field (Ernst, 1979), and the $\mathrm{Si}^{4+}$ isopleth of white mica (Massonne and Schreyer, 1987). The $P-T$ field traced in Fig. 10 places stage II in the range of ca. $500-600{ }^{\circ} \mathrm{C}$ at 0.55 to $0.7 \mathrm{GPa}$.

\subsubsection{Stage III}

Temperatures for the eclogite stage III were calculated using different geothermometer calibrations based on Fe-Mg exchange reactions between garnet and clinopyroxene (Table 6). Fe-Mg exchange thermometry is generally compromised by uncertainties in the $\mathrm{Fe}^{3+}$ / $\mathrm{Fe}_{\text {tot }}$ ratio. In common eclogites the $\mathrm{Fe}^{3+} / \mathrm{Fe}_{\text {tot }}$ ratio in garnet is expected to be low, but extreme caution must be used when applying the calculated $\mathrm{Fe}^{3+} / \mathrm{Fe}_{\text {tot }}$ ratio for omphacite, and especially for $\mathrm{Fe}$-poor systems (Krogh Ravna and Paquin, 2005). In this paper, the $\mathrm{Fe}^{3+} / \mathrm{Fe}_{\text {tot }}$ ratio was calculated in accordance with Ryburn et al. (1976) for both garnet and omphacite.

The thermobarometric data of the eclogitic stage were calculated using garnet and omphacite in well-preserved microtextural occurrences. In particular, taking into consideration the prograde zoning of garnet, the highest $\mathrm{X}_{\mathrm{Mg}}$ regions near the rim of crystals were used to estimate the eclogite stage conditions; for omphacite, low acmite compositions were utilized. The average temperatures calculated under the nominal pressure of $2 \mathrm{GPa}$ were in the range $595-715^{\circ} \mathrm{C}$ for the different calibrations (Table 6), with the lowest average value obtained through the Ai (1994) calibration and the highest average value obtained by the Ellis and Green (1979) calibration. However, the preservation of the prograde zoning suggests that the calibration of Ellis and Green (1979) is likely unrealistic (Table 6). Minimum pressure estimations on the basis of the jadeite content of omphacite in the presence of quartz were ca. 1.5 GPa (Holland, 1983). In addition, in some microtextural domains in which omphacite, garnet, and phengite are in mutual contact, pressure was calculated through the barometer pyrope +2 grossular $=6$ diopside $+3 \mathrm{Al}_{2} \mathrm{Mg}_{-1} \mathrm{Si}_{-1}$ (Waters, 1996), which yielded the average pressure of $1.9 \mathrm{GPa}$ for a nominal temperature of $650{ }^{\circ} \mathrm{C}$. The $P-T$ box in Fig. 10 with $T$ between 595 and $650{ }^{\circ} \mathrm{C}$ and a $P$ of 1.3 to $1.9 \mathrm{GPa}$ represents the best estimate for the eclogite stage.

\subsubsection{Stages $I V$ and $V$}

Retrogression to amphibolite-facies conditions (Table 6) has been evaluated using two different microtextural occurrences: (1) porphyroblastic amphiboles with the enclosed, unzoned, re-equilibrated garnet, and (2) symplectites after omphacite, in which the diopsidic clinopyroxene and albitic plagioclase are associated with amphibole. The former microtextural occurrence permits the application of the thermometer based on the Fe-Mg exchange between amphibole and garnet. Average temperatures are 552 and $610{ }^{\circ} \mathrm{C}$ using the Perchuck et al. (1985) and Graham and Powell (1984) calibrations, respectively. The experimental calibration of Plyusnina (1982) using mineral phases in equilibrium in symplectites yields temperatures of ca. $525^{\circ} \mathrm{C}$ and pressures of $0.8 \mathrm{GPa}$. A comparable temperature $\left(500{ }^{\circ} \mathrm{C}\right)$ was obtained with the qualitative method of Spear (1980), and a higher temperature $\left(598^{\circ} \mathrm{C}\right.$ at $\left.1.0 \mathrm{GPa}\right)$ was obtained through the Holland and Blundy (1994) calibration. For pressure, the jadeite content of diopsidic clinopyroxene yields a value of ca. $1.0 \mathrm{GPa}$ at $600{ }^{\circ} \mathrm{C}$. The $P-T$ box for stage IV in Fig. $10\left(552-610{ }^{\circ} \mathrm{C}\right.$; $0.7-1.0 \mathrm{GPa}$ ) is partly above the isopleth $\mathrm{Si}^{4+}=3.3$ for phengite and overlaps the stability field of barroisite, which is stable during the eclogite stage. The $P-T$ box likely reflects the continuous evolution from the eclogite- to the amphibolite-facies stage during decompression. The $P-T$ box for stage $\mathrm{V}$ (ca. $525-575{ }^{\circ} \mathrm{C}$; ca. $0.4-0.6 \mathrm{GPa}$ ) was determined on the basis of Ca-amphibole compositions (Plyusnina, 1982; Brown, 1977).

\subsubsection{Stage VI}

The assemblage tremolite + chlorite + albitic plagioclase in the late veins is indicative of greenschist-facies conditions, which are constrained at nearly $350-426{ }^{\circ} \mathrm{C}$ and pressures below $0.5 \mathrm{GPa}$ by the amphibole-plagioclase thermometer (Holland and Blundy, 1994), and by the overstepping at decreasing temperature and pressure of the reaction (R9)

Hornblende + zoisite $+\mathrm{CO}_{2}+\mathrm{H}_{2} \mathrm{O}=$ chlorite + plagioclase + quartz + calcite (Plyusnina, 1982)

and by the curve (Ernst, 1979) separating the stability field of actinolite and hornblende.

Table 6

T and P estimates for the eclogites (RO380 and RC0611) and host pelitic schist (227).

\begin{tabular}{|c|c|c|c|c|c|c|c|c|c|c|c|c|c|c|c|c|c|c|}
\hline \multirow{3}{*}{$\frac{\text { Sample }}{\text { RO380 }}$} & \multicolumn{18}{|c|}{ Temperature $\left({ }^{\circ} \mathrm{C}\right)$} \\
\hline & \multirow{2}{*}{$\begin{array}{l}\text { Grt- } \\
\text { Cpx } \\
\mathrm{n}\end{array}$} & \multirow{2}{*}{$\begin{array}{l}\mathrm{EG} \\
\mathrm{T}\end{array}$} & \multirow{2}{*}{$\begin{array}{l}\mathrm{K} \\
\mathrm{T}\end{array}$} & \multirow{2}{*}{$\begin{array}{l}\mathrm{Ai} \\
\mathrm{T}\end{array}$} & \multirow{2}{*}{$\begin{array}{l}\mathrm{P} \\
\mathrm{T}\end{array}$} & \multirow{2}{*}{$\begin{array}{l}\mathrm{R} \\
\mathrm{T}\end{array}$} & \multirow{2}{*}{$\begin{array}{l}\text { Grt- } \\
\text { Cam } \\
\mathrm{n}\end{array}$} & \multirow{2}{*}{$\begin{array}{l}\text { GP } \\
\mathrm{T}\end{array}$} & \multirow{2}{*}{$\begin{array}{l}\mathrm{Pe} \\
\mathrm{T}\end{array}$} & \multirow{2}{*}{$\begin{array}{l}\text { Pl- } \\
\text { Cam } \\
\text { n }\end{array}$} & \multirow{2}{*}{$\begin{array}{l}\text { Ply } \\
\text { T }\end{array}$} & \multirow{2}{*}{$\begin{array}{l}\mathrm{HB} \\
\mathrm{T}\end{array}$} & \multirow{2}{*}{$\begin{array}{l}\text { Tur- } \\
\mathrm{Bt} \\
\mathrm{n}\end{array}$} & \multirow[t]{2}{*}{$\mathrm{CF}$} & \multirow{2}{*}{$\begin{array}{l}\text { Grt- } \\
\mathrm{Bt} \\
\mathrm{n}\end{array}$} & \multirow[t]{2}{*}{ GS } & \multirow[t]{2}{*}{ PL } & \multirow[t]{2}{*}{ KR } \\
\hline & & & & & & & & & & & & & & & & & & \\
\hline Stage III & 9 & $715 \pm 59$ & $666 \pm 66$ & $595 \pm 67$ & $693 \pm 60$ & $625 \pm 63$ & & & & & & & & & & & & \\
\hline Stage IV & & & & & & & 4 & $610 \pm 10$ & $552 \pm 20$ & & & & & & & & & \\
\hline Stage VI & & & & & & & & & & 1 & & 426 & & & & & & \\
\hline RC0611 & & & & & & & & & & & & & & & & & & \\
\hline Stage V & & & & & & & & & & 3 & $525 \pm 0$ & $598 \pm 2$ & & & & & & \\
\hline RO227 & & & & & & & & & & & & & 4 & $639 \pm 21$ & 2 & $737 \pm 8$ & $722 \pm 8$ & $729 \pm 10$ \\
\hline \multicolumn{19}{|c|}{ Pressure (Gpa) } \\
\hline \multirow[t]{2}{*}{ RO380 } & Grt-P & he-Omp & W & $\operatorname{maxXjd}$ & & $\mathrm{H}$ & Cam-Pl & Ply & & & & & & & & & & \\
\hline & & $\mathrm{n}$ & $\mathrm{P}$ & & & $\mathrm{P}$ & $\mathrm{n}$ & $P$ & & & & & & & & & & \\
\hline Stage III & & 4 & $1.9 \pm 0.07$ & 0.34 & & 1.5 & & & & & & & & & & & & \\
\hline RCO611 & & & & & & & & & & & & & & & & & & \\
\hline Stage IV & & & & 0.16 & & 1 & & & & & & & & & & & & \\
\hline Stage V & & & & & & & 3 & $0.8 \pm 0$ & & & & & & & & & & \\
\hline
\end{tabular}

Reported estimates represent the average \pm standard deviation $(2 \sigma)$ of values $(n>1)$ using different couples. Values for $n=1$ refer to a single couple. $n$ : number of couples used for calculation. Calibrations: EG: Ellis and Green (1979); K: Krogh (1988); Ai: Ai (1994); P: Powell (1985); R: Ravna (2000); GP: Graham and Powell (1984); Pe: Perchuck et al. (1985); Ply: Plyusnina (1982); HB: Holland and Blundy (1994); CF: Colopietro and Friberg (1987); GS: Ganguly and Saxena (1984); PL: Perchuck and Lavrent'eva (1983); KR: Kleemann and Reinhardt (1994). 


\subsection{Host schists}

Temperatures (Table 6) were evaluated using the thermometers based on the Fe-Mg exchange biotite-tourmaline (Colopietro and Friberg, 1987) and biotite-garnet (Ganguly and Saxena, 1984; Perchuck and Lavrent'eva, 1983; Kleemann and Reinhardt, 1994). The average temperature is $639 \pm 21{ }^{\circ} \mathrm{C}$ for the biotite-tourmaline thermometer, but higher average values $\left(722 \pm 8\right.$ to $737 \pm 8{ }^{\circ} \mathrm{C}$ ) have been estimated for the biotite-garnet thermometer. The absence of migmatites suggests (with reference to the KFMASH system; Vielzeuf and Holloway, 1988) that the temperature did not exceed $700{ }^{\circ} \mathrm{C}$. The more realistic temperature estimated through the tourmaline-biotite thermometer must, however, be taken with caution because as suggested by Henry and Dutrow (1996) a simple Fe-Mg exchange may not be attained between tourmaline and biotite.

The GASP (garnet-kyanite-quartz-plagioclase) barometer could not be applied because of the low $\mathrm{Ca}$ content of plagioclase $\left(\mathrm{X}_{\mathrm{an}}<17 \%\right)$ (Holdaway, 2001). Pressures were evaluated using the phengite content of muscovite (Massonne and Schreyer, 1987), which gives a minimum value of $0.6 \mathrm{GPa}$ at $600{ }^{\circ} \mathrm{C}$.

\section{P-T-t path of Tasmanian high-pressure rocks}

The petrological data on eclogites from Tasmania provide information not only on the retrograde part of the $P-T-t$ path of the rocks but also on the prograde path.

In particular, the prograde part of the $P-T-\mathrm{t}$ path is based on the petrological data for stages I, II, and III, while data for stages IV, V, and VI constrain the retrograde/decompressional path. Although there is uncertainty for the early stage I, the other metamorphic stages are quite well defined in the $P-T$ field of Fig. 10 . The eclogites from Tasmania followed a steep clockwise metamorphic path. Both prograde and retrograde segments of the reconstructed path are steep, with a similar $\mathrm{d} P / \mathrm{d} T$ between the prograde path and the first portion of the retrograde one. The latter shows nearly isothermal decompression between the eclogite stage and the high-pressure amphibolite-facies stage IV, which was achieved at deep crustal levels $(\approx 30 \mathrm{~km})$, and which was followed by a decrease in both pressure and temperature from deep/intermediate-to-shallow crustal levels with a typical cooling-unloading path. The lack of a complete re-equilibration during the different stages and the high $\mathrm{d} P / \mathrm{d} T$ of both prograde and retrograde segments are indicative of a rapid burial and an initially rapid exhumation.

As with many high-pressure metamorphic terranes (Smith, 1988; Carswell et al., 2000) the host pelitic schists of Tasmania examined in this study also record medium-pressure amphibolite-facies conditions, but they do not show evidence of the prograde path or of higherpressure conditions and show only limited evidence of the retrogressive one. However, the amphibolite-facies retrogression (stages IV and $\mathrm{V}$ ) of eclogites overlaps with the $P-T$ conditions of host schists, and the fact that the latter and their mafic boudins show a contact parallel to the main foliation indicates that they likely followed the same cooling-unloading path from the amphibolite-facies conditions.

$\mathrm{U}-\mathrm{Th} / \mathrm{Pb}$ dating of monazite on different metamorphic rocks from uppermost greenschist to middle amphibolite-facies of western and northern Tasmania indicates a metamorphic age in the range 515-510 Ma (Berry et al., 2007) without any difference of space and type of metamorphism and with the possible peak of metamorphism at about $510 \mathrm{Ma}$. In particular, in the Franklin Metamorphic Complex the new geochronological data refer to the amphibolite-facies metamorphism of the hosting schists, which in turn is coincident with the preferred age for the high-pressure metamorphism of mafic rocks (511 \pm 8 Ma; Black et al., 1997).

The fact that similar ages of metamorphism were obtained for both the eclogites and their hosting schists, that there was a concordant foliation, and that the same $P-T$ conditions were estimated for amphibolite-facies suggests two possibilities: (1) mafic rocks and hosting schists underwent the same evolution, including high-pressure, but the hosting schists were totally re-equilibrated during retrogression; or (2) they attained the peak metamorphism at different crustal levels, at nearly the same age, but mafic rocks were rapidly uplifted and coupled with host rocks at shallower crustal levels, and both developed a common history from amphibolite-facies conditions. Our petrological data cannot permit discrimination between the two possibilities. To resolve this question, it would be necessary to obtain new SRHIMP analysis on zircons from eclogite, as previously suggested by Black et al. (1997), or to discover high-pressure relics in the hosting schists.

\section{Comparison between Tasmania and Antarctica high-pressure rocks and geodynamic implications}

There is general consensus that the Ross, Tyennan, and Delamerian orogenies developed in the geodynamic setting of the early Palaeozoic convergence between the paleo-Pacific plate and the Gondwana margin (Encarnacion and Grunow, 1996; Goodge, 2007). However, the correlation of Cambrian depositional, structural, magmatic, and metamorphic histories along this margin shows differences and often contradictory characteristics that are difficult to reconcile in a single scenario (Squire and Wilson, 2005).

Foden et al. (2006), on the basis of geochronological results, noted that the Ross Orogen began at least 25 m.y. earlier than the Delamerian and Tyennan orogenies, but that they all had a coeval conclusion at nearly $490-480 \mathrm{Ma}$, as suggested by post-tectonic granitoids and $\mathrm{Ar}-\mathrm{Ar}$ mineral ages (Encarnacion and Grunow, 1996; Goodge, 2007; Foden et al., 2006; Foster and Gray, 2000). In particular, the Delamerian/Tyennan events in Australia and Tasmania are nearly synchronous, with the earliest event constrained at $514 \pm 3 \mathrm{Ma}$ and abruptly terminating at $490 \pm 3 \mathrm{Ma}$ (Turner et al., 1998; Foden et al., 2006).

The Ross Orogen in Northern Victoria Land and the Delamerian Belt in southeastern Australia have similar features, such as a lowpressure, high-temperature metamorphic belt (Dymoke and Sandiford, 1992; Talarico et al., 1992) with syn- to post-tectonic magmaticarc granitoids (Borg et al., 1987; Armienti et al., 1990; Rocchi et al., 2004; Foden et al., 2006) and a high P belt (Ricci et al., 1996, 1997; Talarico et al., 1998; Watanabe et al., 1997; Och et al., 2003).

In Northern Victoria Land, the two contrasting metamorphic belts are contiguous and constitute a typical set of paired metamorphic belts (Grew et al., 1984; Ricci et al., 1997). In contrast, in Tasmania there are only a few Cambrian granitoids, and a low-pressure metamorphic belt is lacking, but high-pressure rocks are present (Meffre et al., 2000). The Wilson Terrane of Northern Victoria Land is considered to be the expression of a W-dipping subduction under the Gondwana margin (Kleinschmidt and Tessensohn, 1987; Ricci et al., 1997; Goodge, 2007), whereas an E-dipping subduction is proposed for the arc-continent collision that generated the southwest-directed ophiolite obduction in Tasmania (Crawford and Berry, 1992). An additional unresolved problem arises from the comparison of the coeval (Cambrian) metavolcanic rocks of the Bowers Terrane in Northern Victoria Land and the Mount Read Volcanics in Tasmania. Foster et al. (2005) considered the latter an expression of continental rift magmatism, whereas Crawford and Berry (1992) envisage a post-collisional context. The Bowers Terrane was interpreted as an oceanic volcanic arc with related sediments by Weaver et al. (1984), but new geochemical data that shows compositional variation from N-to-EMORB points to a marginal back-arc basin in an extensional setting that is probably associated with a primitive island arc (Rocchi et al., 2003; Federico et al., 2006).

The Wilson and Bowers Terranes are separated by the Lanterman fault, one of the major tectonic lineaments in Northern Victoria Land and along which metaconglomerates are present (Capponi et al., 1999). 


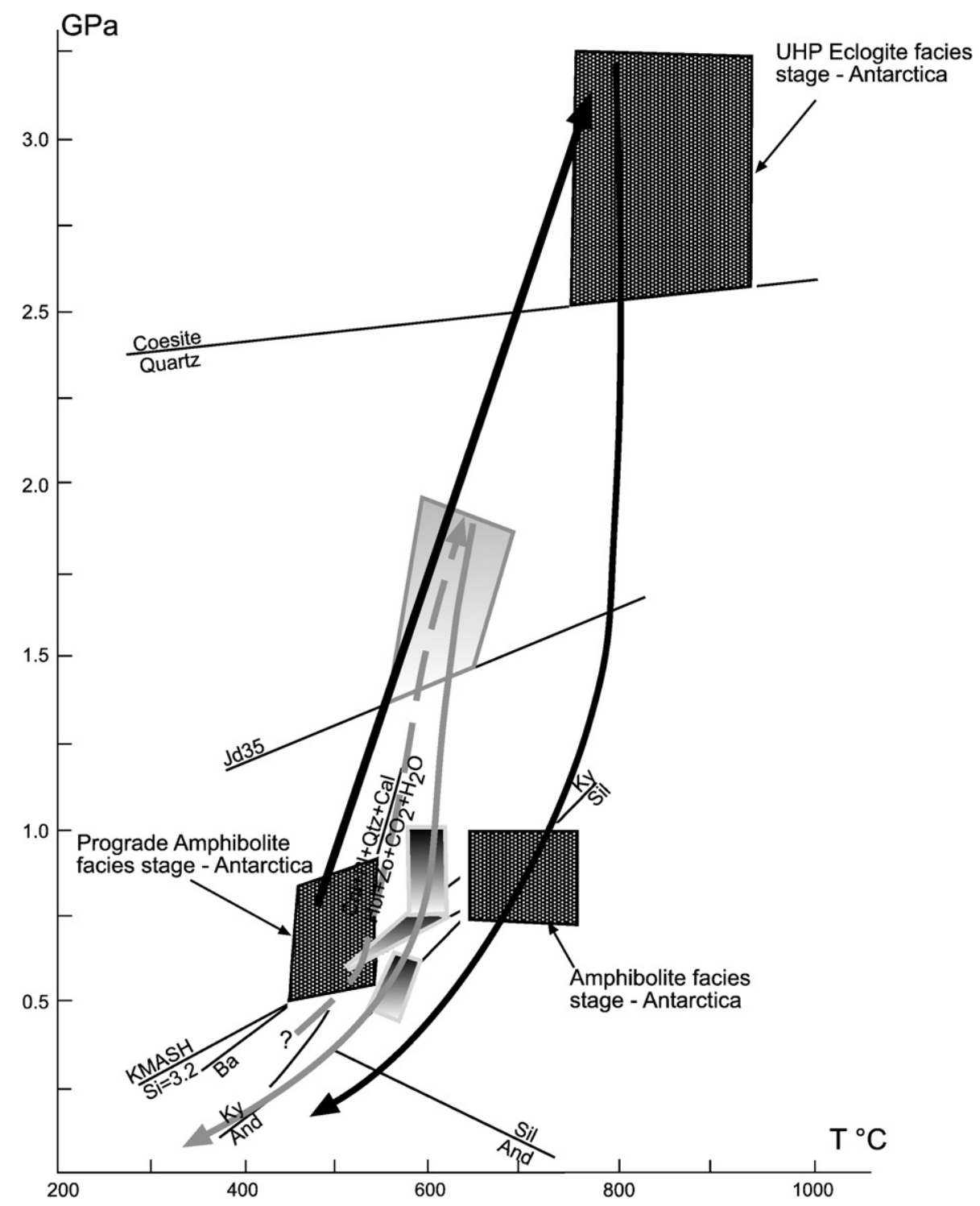

Fig. 11. Comparison of the prograde and retrograde paths of eclogites from Tasmania (grey arrows) and Northern Victoria Land (Antarctica) (black arrows). Reaction curves and grey $P-T$ boxes as in Fig. 10. $P-T$ boxes and the $P-T-t$ path from Antarctica are from Palmeri et al. $(2003 ; 2007)$.

Highly deformed metaconglomerates are felsic, mafic, and ultamafic in composition and also include boninitic rocks (Federico et al., 2006). Such deposits are the product of a rapid exhumation and erosion of the Cambrian basement, including the retrogressed high-pressure rocks. The boninitic clasts in the metaconglomerates were possibly derived from the boninite-type intrusions at the Niagara Icefalls along the Wilson Terrane (Tribuzio et al., 2008). An age of 480-460 Ma (Crispini et al., 2007) is assigned to the structural and metamorphic re-working of these conglomerates.

Upper-Cambrian to lower-Ordovician quartzite-dominated conglomerates are widespread in Tasmania (Meffre et al., 2000). Conglomerates dominated by volcanic and ultramafic clasts are less common and are limited to the Middle Cambrian (Seymour and Calver, 1995). The final difference considered here is the metamorphic evolution reconstructed in this paper for eclogites of Tasmania as compared with those of Northern Victoria Land: although they have similar ages for high-pressure metamorphism (Di Vincenzo et al., 1997; Meffre et al., 2000), strong differences are evident in terms of mineral chemistry (Figs. 4, 6, 7), $P$-T conditions of metamorphic peaks (Fig. 11), and $\mathrm{d} P / \mathrm{d} T$. While the similar mafic whole-rock compositions and metamorphic ages suggest some connection, the different petrological evolutions point to different geodynamic scenarios in these two adjacent sectors of the Gondwana margin during the Ross/ Tyennan orogeny. Foster et al. (2005) suggest a complex arrangement of oceanic and continental microplates developed off the DelamerianRoss margin of Gondwana starting ca. $505 \mathrm{Ma}$ and continuing to ca. $490 \mathrm{Ma}$. The different $P-T$ path of eclogites and the other early Cambrian differences between the two regions could be reconciled by models involving two microplates (Northern Victoria Land and Tasmania) aligned along the Gondwana margin and separated by a transform boundary, as suggested by some authors (Munker and Crawford, 2000; Flöttmann et al., 1998; Foster et al., 2005). The two microplates may have shared the same evolution from the late Cambrian (508-495 Ma), when the exhumation and cratonization of the Delamerian-Ross Orogen began (Foster and Gray, 2000; Foster et al., 2005), but they likely had different evolutions before $508 \mathrm{Ma}$.

\section{Acknowledgments}

This research was carried out with the financial support of MIURPRIN 2006 (C.A. Ricci) and Siena University-PAR 2005 (R. Palmeri).The authors thank R. Bottrill (Department of Infrastructure, Energy and Resources, Tasmania), who provided some of the study samples, and Ron Berry (University of Tasmania) for his comments on the 
manuscript. M. Fialin and F. Couffignal of the Centre d'analyses CAMPARIS (CNRS-Paris) and G. Godard (IPGP-Université VII Paris) are thanked for their assistance with the microprobe analysis. The two anonymous reviewers and the Editors (L. Dobrzhinetskaya and I. Buick) are thanked for the constructive review and editorial handling of the manuscript respectively.

\section{References}

Ai, Y., 1994. A revision of the garnet-clinopyroxene $\mathrm{Fe}^{2+}$-Mg exchange geothermometer Contributions to Mineralogy and Petrology 115, 467-473.

Armienti, P., Ghezzo, C., Innocenti, F., Manetti, P., Rocchi, S., Tonarini, S., 1990. Isotope geochemistry and petrology of granitoid suites from Granite Harbour Intrusives of the Wilson Terrane, North Victoria Land, Antarctica. European Journal of Mineralogy 2, 103-123.

Banno, S., Enami, M., Hirajima, T., Ishiwatari, A., Wang, Q., 2000. Decompression P-T path of coesite eclogite to granulite from Weihai, eastern China. Lithos 52, 97-108.

Berry, R.F., Chmielowski, R.M., Steele, D.A., Meffre, S., 2007. Chemical U-Th-Pb monazite dating of the Cambrian Tyennan Orogeny, Tasmania. Australian Journal of Earth Sciences 54, 757-771.

Berry, R.F., Crawford, A.J., 1988. The tectonic significance of Cambrian allochtonous mafic-ultramafic complexes in Tasmania. Australian Journal of Earth Sciences 35 523-533.

Black, L.P., Seymour, D.B., Corbett, K.D., Cox, S.E., Streit, J.E., Bottrill, R.S., Calver, C.R. Everard, J.L., Green, G.R., McClenaghan, M.P., Pemberton, J., Taheri, J., Turner, N.J., 1997. Dating Tasmania's oldest geological events. AGSO Record, Mineral Resources Tasmania, Australian Geological Survey Organisation. 57 pp.

Bohlen, S.R., Boettcher, A.L., 1982. The quartz-coesite transformation: N pressure determination and the effects of other composition. Journal of Geophysical Research 87, 7073-7078.

Borg, S.G., DePaolo, D.J., 1994. Laurentia, Australia and Antarctica as a Late Proterozoic supercontinent: constraints from isotopic mapping. Geology 22, 307-310.

Borg, S., Stump, E., Chappell, B.W., McCulloch, M.T., Wyborn, D., Armstrong, R.L., Holloway, J.R., 1987. Granitoids of northern Victoria Land, Antarctica: implications of chemical and isotopic variations to regional crustal structure and tectonics. American Journal of Science 287, 127-169.

Brown, E.H., 1977. The crossite content of Ca-amphibole as a guide to pressure of metamorphism. Journal of Petrology 18, 53-72.

Brown, A.V., Calver, C.R., Corbett, K.D., Forsyth, S.M., Goscombe, B.A., Green, G.R. Mclenaghan, M.P., Pemberton, J., Seymour, D.B., Vicary, M.J., 2005. Geology of southwest Tasmania. Geological Atlas 1:250 000 Digital series. Mineral Resources Tasmania, Hobart.

Capponi, G., Crispini, L., Meccheri, M., 1999. The metaconglomerates of the eastern Lanterman Range (northern Victoria Land, Antarctica): new constraints for their interpretation. Antarctic Science 11, 215-225.

Carswell, D.A., 1990. In: Carswell, D.A. (Ed.), Eclogite-facies Rocks. Chapman \& Hall, New York.

Carswell, D.A., Wilson, R.N., Zhai, M., 2000. Metamorphic evolution, mineral chemistry and thermobarometry of schists and orthogneisses hosting ultra-high pressure eclogites in the Dabieshan of central China. Lithos 52, 121-156.

Coleman, R.G., Beatty, L.B., Brannock, W.W., 1965. Eclogites and eclogites: thei differences and similarities. Geological Society of America Bulletin 76, 483-508.

Colopietro, M.R., Friberg, L.M., 1987. Tourmaline-biotite as a potential geothermometer for metapelites, Black Hills, South Dakota. Geological Society of America, Abstracts with Programs 19, 624.

Crawford, A.J., Berry, R.F., 1992. Tectonic implication of Late Proterozoic-early Palaeozoic igneous rocks associations in western Tasmania. Tectonophysics 214, 37-56.

Crispini, L., Di Vincenzo, G., Palmeri, R., 2007. Petrology and 40Ar-39Ar dating of shear zones in the Lanterman Range (northern Victoria Land, Antarctica): Implications for metamorphic and temporal evolution at terrane boundaries. Mineralogy and Petrology 89, 217-249.

Di Vincenzo, G., Palmeri, R., 2001. An ${ }^{40} \mathrm{Ar}-{ }^{39} \mathrm{Ar}$ investigation of high-pressure metamorphism and the retrogressive history of mafic eclogites from the Lanterman Range (Antarctica): Evidence against a simple temperature control on argon transport in amphibole. Contributions to Mineralogy and Petrology 141, 15-35.

Di Vincenzo, G., Palmeri, R., Talarico, F., Andriessen, P.A., Ricci, C.A., 1997. Petrology and geochronology of eclogites from the Lanterman Range, Antarctica. Journal of Petrology 38, 1391-1417.

Dymoke, P., Sandiford, M., 1992. Phase relationships in Buchan facies series pelitic assemblages: calculations with application to andalusite-staurolite parageneses in the Mount Lofty Ranges, South Australia. Contributions to Mineralogy and Petrology 110,121-132.

Ellis, D.J., Green, D.H., 1979. An experimental study of the effect of Ca upon garnetclinopyroxene Fe-Mg exchange equilibria. Contributions to Mineralogy and Petrology 71, 13-22.

Encarnacion, J.P., Grunow, A.M., 1996. Changing magmatic and tectonic styles along the paleo-Pacific margin of Gondwana and the onset of the Paleozoic magmatism in Antarctica. Tectonics 15, 1325-1341.

Ernst, W.G., 1979. Coexisting sodic and calcic amphiboles from high-pressure metamorphic belts and the stability of barroisitic amphibole. Mineralogical Magazine 43, 269-278.

Essene, E.J., Fyfe, W.S., 1967. Omphacite in California metamorphic rocks. Contributions to Mineralogy and Petrology 15, 1-23.
Federico, L., Capponi, G., Crispini, L., 2006. The Ross Orogeny of the Transantarctic Mountains: a northern Victoria Land perspective. International Journal of Earth Science 95, 759-770

Flöttmann, T., Gibson, G.M., Kleinschmidt, G., 1993. Structural continuity of the Ross and Delamerian orogens of Antarctica and Australia along the margin of the paleoPacific. Geology 21, 319-322.

Flöttmann, T., Haines, P., Jago, J., James, P., Belperio, A., Gum, J., 1998. Formation and reactivation of the Cambrian Kanmantoo Trough, SE Australia: implications for early Palaeozoic tectonics at eastern Gondwana's plate margin. Journal of Geological Society of London 155, 525-539.

Foden, J., Elburg, M.A., Dougherty-Page, J., Burtt, A., 2006. The timing and duration of the Delamerian Orogeny: correlation with the Ross orogen and implications for Gondwana assembly. Journal of Geology 114, 189-210.

Foster, D.A., Gray, D.R., 2000. Evolution and structure of the Lachlan Fold Belt of eastern Australia. Annual Review Earth Planetary Science 28, 47-80.

Foster, D.A., Gray, D.R., Spaggiari, C., 2005. Timing of subduction and exhumation along the Cambrian East Gondwana margin, and the formation of Paleozoic backarc basins. Geological Society of America Bulletin 117, 105-116.

Ganguly, J., Saxena, S.K., 1984. Mixing properties of aluminosilicate garnets: constraints from natural and experimental data, and applications to geothermo-barometry. American Mineralogist 69, 88-97.

Goodge, J.W., 2007. Metamorphism in The Ross orogen and its bearing on Gondwana margin tectonics. Geological Society of America Special Paper 419, 185-203.

Graham, C.M., Powell, R., 1984. A garnet-hornblende geothermometer: calibration testing and application to the Pelona schist, southern California. Journal of Metamorphic Geology 2,13-31.

Grew, E.S., Kleinschmidt, G., Schubert, W., 1984. Contrasting metamorphic belts in North Victoria Land, Antarctica. In: Roland, N.W. (Ed.), German Antarctic North Victoria Land Expedition 1982/83, GANOVEX III. Geological Jahrbuch, vol. B60, pp. 253-263.

Hawthorne, F.C., Oberti, R., 2007. Classification of the amphiboles. Reviews in Mineralogy \& Geochemistry 67, 55-88.

Henry, D.J., Dutrow, B.L., 1996. Metamorphic tourmaline and its petrological applications. In: Grew, E.S., Anovitz, L.M. (Eds.), Boron: Mineralogy, Petrology and Geochemistry. Reviews in Mineralogy \& Geochemistry, vol. 33, pp. 503-557.

Holdaway, M.J., 1971. Stability of andalusite and the aluminium silicate phase diagram. American Journal of Science 271, 97-131.

Holdaway, M.J., 2001. Recalibration of the GASP geobarometer in light of recent garnet and plagioclase activity models and versions of the garnet-biotite geothermometer. American Mineralogist 86, 1117-1129.

Holland, T.J.B., 1983. The experimental determination of activities in disordered and short-range ordered jadeitic pyroxenes. Contributions to Mineralogy and Petrology $82,214-220$.

Holland, T.J.B., Blundy, J.D., 1994. Non-ideal interactions in calcic amphiboles and their bearing on amphibole-plagioclase thermometry. Contributions to Mineralogy and Petrology 116, 433-447.

Holland, T.J.B., Powell, R., 1998. An internally consistent thermodynamic data set fo phases of petrological interest. Journal of Metamorphic Geology 16, 309-343.

Kamperman, M., 1984. The Precambrian metamorphic geology of the Lyell HighwayCollingwood River area. BSc (Hons) thesis, University of Tasmania, Hobart.

Kleemann, U., Reinhardt, J., 1994. Garnet-biotite thermometry revisited: the effect of $\mathrm{Al}^{\mathrm{VI}}$ and Ti in biotite. European Journal of Mineralogy 6, 925-941.

Kleinschmidt, G., Tessensohn, F., 1987. Early Paleozoic westward subduction at the Pacific margin of Antarctica. In: McKenzie, G.D. (Ed.), Gondwana Six: Structure, tectonics and geophysics, Geophysical Monograph, vol. 40. American Geophysical Union, pp. 89-105.

Klemd, R., Matthes, S., Okrusch, M., 1991. High-pressure relics in metasediments intercalated with the Weissenstein eclogite, Munchberg gneiss complex, Bavaria. Contributions to Mineralogy and Petrology 107, 328-342.

Kretz, R., 1983. Symbols for rock-forming minerals. American Mineralogist 68, 277-279.

Krogh Ravna, E.J., Paquin, J., 2005. Thermobarometric methodologies applicable to eclogites and garnet ultrabasites. In: Carswell, A.A., Compagnoni, R. (Eds.), Ultrahigh pressure metamorphism. EMU notes in Mineralogy, 5, pp. 229-260.

Krogh, E.J., 1988. The garnet-clinopyroxene Fe-Mg geothermometer-a reinterpretation of existing experimental data. Contributions to Mineralogy and Petrology 99, 44-48.

Laird, J., Albee, A.L., 1981. Pressure, temperature and time indicators in mafic schist: Their application to reconstructing the polymetamorphic history of Vermont. American Journal of Science 281, 127-175.

Leake, B.E., et al., 1997. Nomenclature of amphiboles. Report of the subcommittee on amphiboles of the International mineralogical association commission on new minerals and mineral names. European Journal of Mineralogy 9, 623-651.

Massonne, H.J., Schreyer, W., 1987. Phengite geobarometry based on the limiting assemblage with K-feldspar, phlogopite, and quartz. Contributions to Mineralogy and Petrology 96, 212-224.

Meffre, S., Berry, R.F., Hall, M., 2000. Cambrian metamorphic complexes in Tasmania: tectonic implications. Australian Journal of Earth Science 47, 971-985.

Munker, C., Crawford, A.J., 2000. Cambrian arc evolution along the SE Gondwana active margin: a synthesis from Tasmania-New Zealand-Australia-Antarctica correlations. Tectonics 19, 415-432.

Och, D.J., Leitch, E.C., Caprarelli, G., Watanabe, T., 2003. Blueschist and eclogite in tectonic melange, Port Macquarie, New South Wales, Australia. Mineralogical Magazine 67, 609-624.

Palmeri, R., Ghiribelli, B., Ranalli, G., Talarico, F., Ricci, C.A., 2007. Ultrahigh-pressure metamorphism and exhumation of garnet-bearing ultramafic rocks from the Lanterman Range (northern Victoria Land, Antarctica). Journal of Metamorphic Geology, 25, 225-243. 
Palmeri, R., Ghiribelli, B., Talarico, F., Ricci, C.A., 2003. Ultra-high-pressure metamorphism in felsic rocks: the garnet-phengite gneisses and quartzites from the Lanterman Range, Antarctica. European Journal of Mineralogy 15, 513-525.

Perchuck, L.L., Aranovich, L.Y.A., Podleskii, K.K., Lavrent'eva, I.V., Gerasimov, V.Y., Kitsul, V.I., Karsakov, L.P., Berokinov, N.V., 1985. Precambrian granulites of the Aldan shield, eastern Siberia, USSR. Journal of Metamorphic Geology 31, 265-310.

Perchuck, L.L., Lavrent'eva, I.V., 1983. Experimental investigation of exchange equilibria in the system cordierite-garnet-biotite. In: Saxena, S.K. (Ed.), Kinetics and Equilibrium in Mineral Reactions. Springer Verlag, New York, pp. 199-240.

Plyusnina, L.P., 1982. Geothermometry and geobarometry of plagioclase-hornblendebearing assemblages. Contributions to Mineralogy and Petrology 80,140-146.

Powell, R., 1985. Regression diagnostic and robust regression in geothermometer/ geobarometer calibration: the garnet-clinopyroxene geothermometer revisited. Journal of Metamorphic Geology 3, 327-342.

Ravna, E.J.K., 2000. The garnet-clinopyroxene geothermometer: an updated calibration. Journal of Metamorphic Geology 18, 211-219.

Reed, A.R., Calver, C., Bottrill, R.S., 2002. Palaeozoic suturing of eastern and western Tasmania in the west Tamar region: implications for the tectonic evolution of southeast Australia. Australian Journal of Earth Sciences 49, 809-830.

Ricci, C.A. Talarico, F. Palmeri, R., Di Vincenzo, G. Pertusati, P.C., 1996. Eclogite at the Antarctic Paleo-Pacific active margin of Gondwana (Lanterman Range, northern Victoria Land, Antarctica). Antarctic Science 8, 277-280.

Ricci, C.A., Talarico, F., Palmeri, R., 1997. Tectonothermal evolution of the Antarctic paleo-Pacific active margin of Gondwana: a northern Victoria Land perspective. In: Ricci, C.A. (Ed.), The Antarctic Region: Geological Evolution and Processes. Terra Antartica Publications, Siena, Italy, pp. 213-218.

Rocchi, S., Capponi, G., Crispini, L., Di Vincenzo, G., Ghezzo, C., Meccheri, M., Palmeri, R., 2003. Mafic rocks at the Wilson-Bowers Terrane transition and within the Bowers Terrane: implications for a geodynamic model of the Ross Orogeny. Terra Antartica Reports 9, 145-148.

Rocchi, S., Di Vincenzo, G., Ghezzo, C., 2004. The Terra Nova Intrusive Complex (Victoria Land, Antarctica). In: Rocchi, S., Di Vincenzo, G., Ghezzo, C. (Eds.), Terra Antartica Reports 10,1-49 + map.

Ryburn, R.J., Raheim, A., Green, D.H., 1976. Determination of the $P-T$ paths of natural eclogites during metamorphism, a record of subduction. A correction. Lithos 9 , 161-165.

Seymour, D.B., Calver, C.R., 1995. Explanatory notes for the time-space diagram and stratotectonic elements map of Tasmania. Tasmanian Geological Survey record 1995/01. $61 \mathrm{pp}$.

Smith, D.C., 1988. In: Smith, D.C. (Ed.), Eclogites and eclogite-facies rocks. Elsevier, Amsterdam, pp. 1-178.
Spear, F.S., 1980. NaSi-CaAl exchange equilibrium between plagioclase and amphiboles. An empirical model. Contributions to Mineralogy and Petrology 72, 33-41.

Spear, F.S., 1993. Metamorphic phase equilibria and pressure-temperature-time paths. Mineralogical Society of America, Monograph 1, Washington, D.C. p. 799

Spry, A.H., 1963. The occurrence of eclogite on the Lyell Highway, Tasmania. Mineralogical Magazine 33, 589-593.

Squire, R.J., Wilson, R.J., 2005. Interaction between collisional orogenesis and convergent-margin processes: evolution of the Cambrian proto-Pacific margin of East Gondwana. Journal of Geological Society of London 162, 749-761.

Talarico, F., Ghiribelli, B., Smith Siddoway, C., Palmeri, R., Ricci, C.A., 1998. The northern Victoria Land segment of the Antarctic paleo-Pacific margin of eastern Gondwana: new constraints from the Lanterman and Mountaineer Ranges. Terra Antartica 5, 245-252.

Talarico, F., Franceschelli, M., Lombardo, B., Palmeri, R., Pertusati, P.C., Rastelli, N., Ricci, C.A., 1992. Metamorphic facies of the Ross orogeny in the southern Wilson Terrane of northern Victoria Land, Antarctica. In: Yoshida, Y., et al. (Ed.), Recent Progress in Antarctic Earth Science. TERRAPUB, Tokio, pp. 211-218.

Tracy, R.J., 1982. Compositional zoning and inclusions in metamorphic minerals. American Mineralogist, Review in Mineralogy 10, 355-397.

Tribuzio, R., Tiepolo, M., Fiameni, S., 2008. A mafic-ultramafic cumulate sequence derived from boninite-type melts (Niagara Icefalls, northern Victoria Land, Antarctica. Contributions to Mineralogy and Petrology 155, 619-633.

Turner, N.J., Black, L.P., Kamperman, M., 1998. Dating Neoproterozoic and Cambrian orogenies in Tasmania. Australian Journal of Earth Sciences 45, 789-806.

Turner, N.J., Bottrill, R.S., 2001. Blue amphibole, Arthur Metamorphic Complex, Tasmania: composition and regional tectonic setting. Australian Journal of Earth Sciences 48, 167-181.

Vielzeuf, D., Holloway, J.R., 1988. Experimental determination of the fluid-absent melting relations in the pelitic system. Contributions to Mineralogy and Petrology 98, 257-276.

Watanabe, T., Leitch, E.C., Fanning, M., 1997. The age and tectonic significance of lawsonite eclogite and high temperature eclogite blocks in serpentinite mélange from the southern New England Fold Belt, eastern Australia. Terra Nova 9, 110 IEC 97 abstract supplement.

Waters, D.J., 1996. The garnet-Cpx-phengite barometer. Recommended calibration and calculation method, updated 1 March 1996. http://www.earth.ox.ac.uk/daveva/ research/ecbar.html.

Waters, D.J., Martin, H.N., 1993. Geobarometry of phengite-bearing eclogites. Terra Abstract 5, 410-411.

Weaver, S.D., Bradshaw, J.D., Laird, M.G., 1984. Geochemistry of Cambrian volcanics of the Bowers Supergroup and implications for the early Paleozoic tectonic evolution of northern Victoria Land, Antarctica. Earth and Planetary Sciences Letters 68, 128-140. 